\title{
Consequences of Intrauterine Growth Restriction for the Kidney
}

\author{
Michiel Schreuder ${ }^{\mathrm{a}}$ Henriette Delemarre-van de Waal ${ }^{\mathrm{b}}$ Ans van Wijk ${ }^{\mathrm{a}}$ \\ Departments of a Pediatric Nephrology and ${ }^{b}$ Pediatric Endocrinology, VU University Medical Center, \\ Amsterdam, The Netherlands
}

\section{Key Words}

Intrauterine growth restriction - Low birth weight • Nephrogenesis · Glomerular number • Kidney function • Glomerular hyperfiltration - Glomerulosclerosis · Renin-angiotensin system • Nitric oxide • Insulin-like growth factor I

\begin{abstract}
Low birth weight due to intrauterine growth restriction is associated with various diseases in adulthood, such as hypertension, cardiovascular disease, insulin resistance and endstage renal disease. The purpose of this review is to describe the effects of intrauterine growth restriction on the kidney. Nephrogenesis requires a fine balance of many factors that can be disturbed by intrauterine growth restriction, leading to a low nephron endowment. The compensatory hyperfiltration in the remaining nephrons results in glomerular and systemic hypertension. Hyperfiltration is attributed to several factors, including the renin-angiotensin system (RAS), insulin-like growth factor (IGF-I) and nitric oxide. Data from human and animal studies are presented, and suggest a faltering IGF-I and an inhibited RAS in intrauterine growth restriction. Hyperfiltration makes the kidney more vulnerable during additional kidney disease, and is associated with glomerular damage and kidney failure in the long run. Animal studies have provided a possible therapy with blockage of
\end{abstract}

the RAS at an early stage in order to prevent the compensatory glomerular hyperfiltration, but this is far from being applicable to humans. Research is needed to further unravel the effect of intrauterine growth restriction on the kidney.

Copyright $\odot 2006$ S. Karger AG, Basel

\section{Introduction}

In recent years, evidence has mounted on the relation between low birth weight (LBW) and diseases in adulthood. Since Barker and Osmond [1] linked a higher incidence of cardiovascular disease with the fetal environment, intrauterine growth restriction (IUGR) is used to explain the association between LBW and raised blood pressure, insulin resistance and non-insulin-dependent diabetes mellitus, dyslipidemia and end-stage renal disease (ESRD) [2-10]. In this review we discuss the broad range of the literature on the effects of IUGR on the kidney.

\section{Kidney Development}

Three different renal organs are formed during fetal life, the pronephros, mesonephros and metanephros [11, 12 . The first two degrade, but the latter becomes the per-

\section{KARGER \\ Fax +41613061234 E-Mail karger@karger.ch} www.karger.com (c) 2006 S. Karger AG, Basel

$1420-4096 / 06 / 0292-0108 \$ 23.50 / 0$

Accessible online at:

www.karger.com/kbr
M.F. Schreuder

Department of Pediatric Nephrology

VU University Medical Center, PO Box 7057

NL-1007 MB Amsterdam (The Netherlands)

Tel. +31 20444 2419, Fax +31 20444 2918, E-Mail mf.schreuder@vumc.nl 
manent kidney. Through various complex and partly understood interactions between metanephros and the ureteric bud, nephrons start to form from day 30 of gestation in humans $[11,12]$. Numerous factors have been identified as requisites for nephrogenesis, such as the renin-angiotensin system (RAS) [13-19], various growth factors [20-27], apoptosis [25, 28-34], and an adequate supply of nutrients [17, 35-38]. Around the 36th gestational week the formation of nephrons ceases [39-42], at which time there are around 600,000-800,000 nephrons per kidney with a wide interindividual range $(250,000-2,000,000)$ [43-54].

\section{Intrauterine Growth Restriction}

Renal development is influenced by any insult disturbing the fine balance in the interactions that form the kidney. In humans, the most important factors influencing fetal development are malnutrition (especially in poor countries) and uteroplacental insufficiency (primary cause of IUGR in western countries) $[55,56]$. Another hypothesis that explains the LBW and diseases in later life is based on excessive exposure to glucocorticoids in the fetus due to inhibition of the placental enzyme $11 \beta$ hydroxysteroid dehydrogenase [57]. This enzyme converts active steroids into inactive metabolites, thereby protecting the fetus from overexposure of endogenous steroids. If the $11 \beta$-hydroxysteroid dehydrogenase is inhibited or if the fetus is exposed to exogenous steroids, fetal growth is inhibited [57].

The resulting IUGR leads to a lower number of nephrons [58-61]. An inverted relationship has been shown between birth weight and nephron number, even in individuals with an appropriate birth weight for gestational age $[53,61-63]$. Irrespective of birth size, premature birth can also disturb nephrogenesis and lead to a nephron deficit $[64,65]$. Kidney dimensions on ultrasound have been shown to be a marker for the number of nephrons in primates [66], and are reduced in late gestation [67-72], in the first year of life [73-75], and in childhood $[75,76]$ after IUGR. Kidney weight is also reduced in childhood [77].

The low nephron endowment will lead to a compensation in the residual nephrons [78], resulting in hypertrophy and hyperfiltration [79]. However, this adaptation may have adverse effects in the long run according to the hyperfiltration theory [79-83]: by reabsorbing more sodium and raising glomerular pressure, systemic blood pressure rises and albuminuria may develop. This results in sclerosis of glomeruli, culminating in a vicious circle which may continue to ESRD [80,83-86]. The prevalence of ESRD indeed is higher in populations with increased rates of LBW [87-90]. The nephron number is inversely related to glomerular volume [63], and glomerular enlargement is found in these ethnic groups with a high incidence of hypertension and progressive renal disease [91, 92], both associated with IUGR [5, 6]. Hayman et al. [93] described in 1939 an association between nephron number and hypertension. An autopsy study in humans from Keller et al. [94] confirms the link between hypertension and fewer, but larger glomeruli, providing evidence for a low number of glomeruli as an explanation for primary hypertension.

A study in rats, using prenatal dexamethasone, shows that there is only a reduction in nephrons when administered on days 15-16 and 17-18 which coincides with an increase in blood pressure [95], again linking the nephron number with hypertension. After maternal protein restriction in the rat, a direct association between blood pressure and glomerular number has also been established [96].

Another renal mechanism that can explain the association between IUGR and hypertension is based on an increased tubular sodium reabsorption. Manning et al. [97] have shown upregulation at both the mRNA and protein level of two critical renal sodium transporters, i.e. bumetadine-sensitive $\mathrm{Na}-\mathrm{K}-2 \mathrm{Cl}$ cotransporter (BSC1) and thiazide-sensitive $\mathrm{Na}-\mathrm{Cl}$ cotransporter (TSC).

\section{Animal Models}

In order to study the effects of IUGR on the kidney, various animal models have been used. Some studies utilize naturally occurring IUGR animals [98-104]. Methods to induce fetal growth restriction are based on maternal deprivation of nutrients (total intake [105-118] or a component like protein [34,119-143], vitamin A [144], sodium [145, 146] or iron [147, 148]), placental embolization $[149,150]$, surgical reduction of placental blood flow [104, 123, 151-163], or the use of steroids [95, 164-172]. Tables 1-3 provide an overview of the effects of nongenetic IUGR on kidney morphology and function in various animal studies. The results of these animal models of IUGR show that marked structural and functional alterations take place in the kidney. The most important systems that are associated with the low glomerular number will be discussed below, and are depicted in figure 1. 
Table 1. Effect of IUGR on renal macroscopic morphology

\begin{tabular}{|c|c|c|c|}
\hline & Animal & IUGR method & References \\
\hline \multicolumn{4}{|c|}{ Kidney weight } \\
\hline Increased & & & None \\
\hline Unaltered & $\begin{array}{l}\text { Monkey } \\
\text { Sheep } \\
\text { Rat }\end{array}$ & $\begin{array}{l}\text { Maternal steroids } \\
\text { Naturally occurring } \\
\text { Maternal steroids } \\
\text { Naturally occurring } \\
\text { Uterine artery ligation } \\
\text { Maternal steroids } \\
\text { Maternal food restriction } \\
\text { Maternal protein restriction } \\
\text { Maternal iron restriction }\end{array}$ & $\begin{array}{l}164 \\
98 \\
166,169,172 \\
101,103,104 \\
104,152,158-160 \\
165,171 \\
105,115 \\
121,127,133,134,136,137,139,143 \\
148\end{array}$ \\
\hline Decreased & $\begin{array}{l}\text { Rabbit } \\
\text { Guinea pig } \\
\text { Rat }\end{array}$ & $\begin{array}{l}\text { Naturally occurring } \\
\text { Placental embolization } \\
\text { Caruncle removal } \\
\text { Maternal steroids } \\
\text { Maternal food restriction } \\
\text { Uterine artery ligation } \\
\text { Uterine artery ligation } \\
\text { Maternal food restriction } \\
\text { Maternal steroids } \\
\text { Maternal food restriction } \\
\text { Maternal protein restriction } \\
\text { Maternal sodium restriction } \\
\text { Maternal vitamin A restriction }\end{array}$ & $\begin{array}{l}99,102,219 \\
149,150 \\
154 \\
169 \\
116 \\
153 \\
151,163 \\
113 \\
168 \\
106,107,110-112,117 \\
125,135,141 \\
145 \\
144\end{array}$ \\
\hline Relative kid & eight & & \\
\hline Increased & Rat & $\begin{array}{l}\text { Maternal steroids } \\
\text { Maternal protein restriction } \\
\text { Maternal iron restriction }\end{array}$ & $\begin{array}{l}171 \\
132 \\
147,148\end{array}$ \\
\hline Unaltered & $\begin{array}{l}\text { Guinea pig } \\
\text { Rat }\end{array}$ & $\begin{array}{l}\text { Naturally occurring } \\
\text { Placental embolization } \\
\text { Caruncle removal } \\
\text { Maternal steroids } \\
\text { Uterine artery ligation } \\
\text { Maternal food restriction } \\
\text { Naturally occurring } \\
\text { Uterine artery ligation } \\
\text { Maternal steroids } \\
\text { Maternal food restriction } \\
\text { Maternal protein restriction } \\
\text { Maternal sodium restriction }\end{array}$ & $\begin{array}{l}219 \\
149,150 \\
154 \\
166,169,170 \\
151,157,163 \\
113 \\
101,103,104 \\
104 \\
168 \\
108,109,111,117,118 \\
121,127,129,133,134,136-138,141 \\
145\end{array}$ \\
\hline Decreased & Rat & $\begin{array}{l}\text { Maternal food restriction } \\
\text { Maternal protein restriction }\end{array}$ & $\begin{array}{l}106,110,112,115 \\
126,128,174\end{array}$ \\
\hline
\end{tabular}


Table 2. Effect of IUGR on renal microscopic morphology

\begin{tabular}{|c|c|c|c|}
\hline & Animal & IUGR method & References \\
\hline \multicolumn{4}{|c|}{ Nephron number } \\
\hline Increased & & & None \\
\hline Unaltered & $\begin{array}{l}\text { Sheep } \\
\text { Rat }\end{array}$ & $\begin{array}{l}\text { Placental embolization } \\
\text { Naturally occurring } \\
\text { Maternal sodium restriction }\end{array}$ & $\begin{array}{l}150 \\
101 \\
145\end{array}$ \\
\hline Decreased & $\begin{array}{l}\text { Pig } \\
\text { Sheep } \\
\text { Rabbit } \\
\text { Guinea pig } \\
\text { Rat }\end{array}$ & $\begin{array}{l}\text { Naturally occurring } \\
\text { Naturally occurring } \\
\text { Maternal steroids } \\
\text { Maternal food restriction } \\
\text { Uterine artery ligation } \\
\text { Uterine artery ligation } \\
\text { Naturally occurring } \\
\text { Uterine artery ligation } \\
\text { Maternal steroids } \\
\text { Maternal food restriction } \\
\text { Maternal protein restriction } \\
\text { Maternal iron restriction } \\
\text { Maternal vitamin A restriction }\end{array}$ & $\begin{array}{l}102 \\
98 \\
172 \\
116 \\
153 \\
157 \\
104 \\
104,123,155 \\
95,165,167,168 \\
106,112,118 \\
34,120,123,128,130,131, \\
133-136,139-143 \\
148 \\
144\end{array}$ \\
\hline \multicolumn{4}{|c|}{ Glomerular size } \\
\hline Increased & Rat & $\begin{array}{l}\text { Naturally occurring } \\
\text { Uterine artery ligation } \\
\text { Maternal food restriction } \\
\text { Maternal protein restriction }\end{array}$ & $\begin{array}{l}104 \\
104 \\
106,112,114 \\
134\end{array}$ \\
\hline Unaltered & $\begin{array}{l}\text { Sheep } \\
\text { Rat }\end{array}$ & $\begin{array}{l}\text { Placental embolization } \\
\text { Maternal protein restriction } \\
\text { Maternal sodium restriction } \\
\text { Maternal iron restriction }\end{array}$ & $\begin{array}{l}150 \\
135,136,141 \\
145 \\
148\end{array}$ \\
\hline Decreased & & & None \\
\hline \multicolumn{4}{|l|}{ Sclerosis } \\
\hline Increased & Rat & $\begin{array}{l}\text { Maternal steroids } \\
\text { Maternal food restriction }\end{array}$ & $\begin{array}{l}167 \\
109,114\end{array}$ \\
\hline Unaltered & Rat & $\begin{array}{l}\text { Naturally occurring } \\
\text { Uterine artery ligation } \\
\text { Maternal steroids } \\
\text { Maternal protein restriction }\end{array}$ & $\begin{array}{l}103,104 \\
104,162 \\
95,171 \\
134\end{array}$ \\
\hline Decreased & & & None \\
\hline \multicolumn{4}{|l|}{ Apoptosis } \\
\hline Increased & Rat & $\begin{array}{l}\text { Uterine artery ligation } \\
\text { Maternal protein restriction }\end{array}$ & $\begin{array}{l}155 \\
34,133\end{array}$ \\
\hline Unaltered & & & None \\
\hline Decreased & & & None \\
\hline
\end{tabular}


Table 3. Effect of IUGR on renal function

\begin{tabular}{|c|c|c|c|}
\hline & Animal & IUGR method & References \\
\hline \multicolumn{4}{|l|}{ GFR } \\
\hline Increased & Rat & Uterine artery ligation & 159,162 \\
\hline \multirow[t]{4}{*}{ Unaltered } & \multirow[t]{4}{*}{ Rat } & Naturally occurring & 103 \\
\hline & & Uterine artery ligation & 156 \\
\hline & & Maternal steroids & $95,168,171,172$ \\
\hline & & Maternal protein restriction & $128,129,134,139$ \\
\hline \multirow[t]{3}{*}{ Decreased } & Pig & Naturally occurring & $99,100,102$ \\
\hline & \multirow{2}{*}{ Rat } & Maternal food restriction & $109,111,112,114$ \\
\hline & & Maternal protein restriction & 119,141 \\
\hline \multicolumn{4}{|c|}{ Urinary albumin excretion } \\
\hline \multirow[t]{5}{*}{ Increased } & \multirow[t]{5}{*}{ Rat } & Naturally occurring & 103,104 \\
\hline & & Uterine artery ligation & 104,159 \\
\hline & & Maternal steroids & 165 \\
\hline & & Maternal food restriction & $109,112,114$ \\
\hline & & Maternal protein restriction & 129 \\
\hline \multirow[t]{5}{*}{ Unaltered } & \multirow[t]{5}{*}{ Rat } & Naturally occurring & 101 \\
\hline & & Uterine artery ligation & 162 \\
\hline & & Maternal steroids & 171 \\
\hline & & Maternal food restriction & 111 \\
\hline & & Maternal protein restriction & 135 \\
\hline \multicolumn{3}{|l|}{ Decreased } & None \\
\hline \multicolumn{4}{|c|}{$\mathrm{Na}$ excretion } \\
\hline \multicolumn{3}{|l|}{ Increased } & None \\
\hline \multirow[t]{4}{*}{ Unaltered } & Pig & Naturally occurring & 99,100 \\
\hline & Rat & Uterine artery ligation & 156 \\
\hline & & Maternal steroids & 168 \\
\hline & & Maternal food restriction & $106,109,114$ \\
\hline \multirow[t]{2}{*}{ Decreased } & \multirow[t]{2}{*}{ Rat } & Maternal food restriction & 111 \\
\hline & & Maternal sodium restriction & 145,146 \\
\hline
\end{tabular}

\section{Renin-Angiotensin System}

The RAS plays an important role in the regulation of capillary resistance and composition and volume of the extracellular fluid, especially the distribution of sodium [13]. These factors are closely interrelated with systemic blood pressure and with renal hemodynamics. A normal functioning RAS is also necessary for normal nephrogenesis [13-19]. An inhibition of the RAS in utero can therefore play a role in the etiology of a low nephron number after IUGR. In fact, a low plasma renin activity (PRA) $[133,173]$ and reduced levels of renal renin protein and mRNA [134] have been described in newborn IUGR rats, even though the results are nonequivocal [174]. However, abnormal maturation of the RAS in the human fetal kidney has been described after IUGR [175], and the RAS does not seem to be inhibited by IUGR, but rather increased: PRA is raised in cord blood of LBW babies, both in utero $[176,177]$ and at birth $[69,178]$. This may be a compensatory mechanism for a faltering nephrogenesis due to a deficiency of another growth factor. Other animal models show changes in the RAS that are more in line with the results in humans. In fetal sheep, gene expression of the RAS is upregulated after maternal steroid treatment [166] leading to a fetal expression that resembles the normal neonatal phase suggesting a premature maturation of the fetal kidney. However, removal of endometrial caruncles, leading to fetal hypoxia and IUGR, 
Fig. 1. Potential mechanisms leading to low glomerular number and subsequent hypertension.

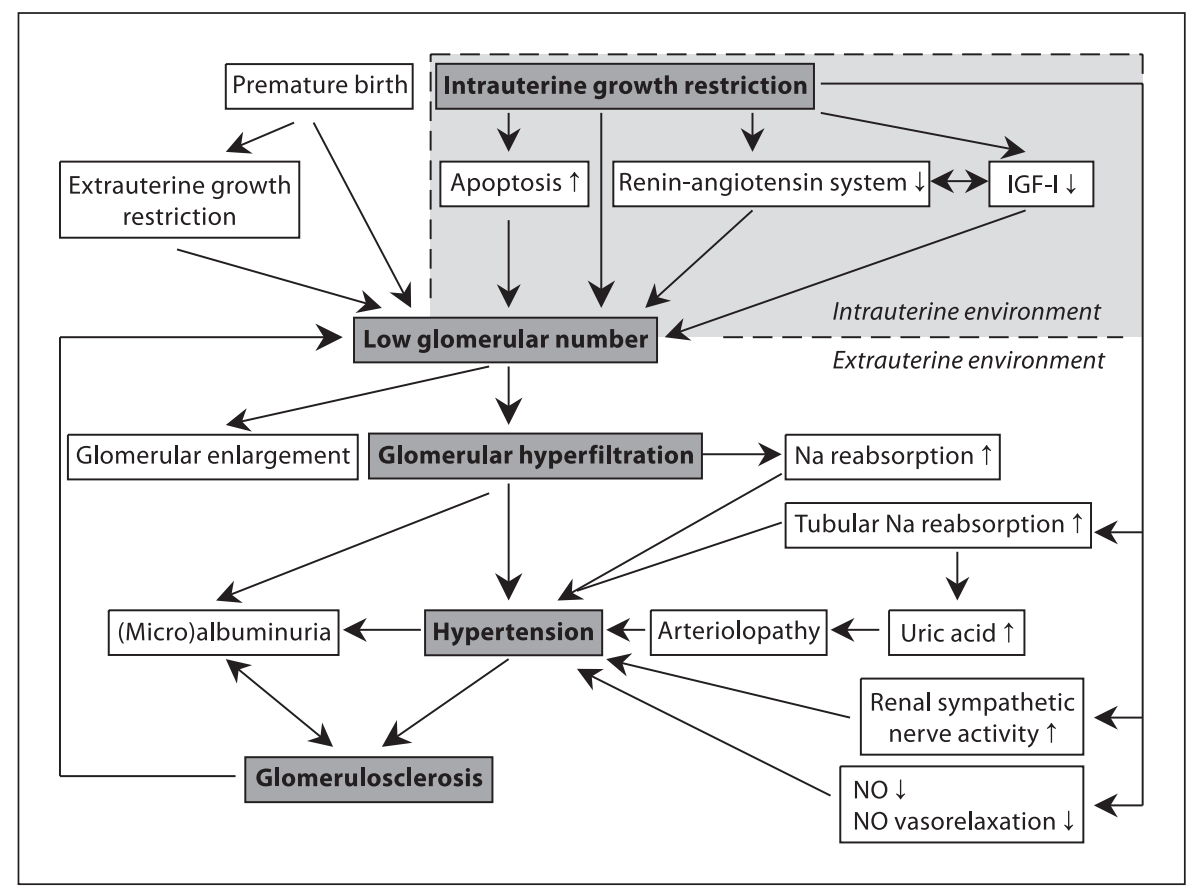

was associated with similar plasma renin concentrations, but reduced levels of renin and angiotensinogen mRNA [154], and treatment with cortisol reduces renin mRNA expression [179]. Fetal treatment with dexamethasone in sheep increases pulmonary angiotensin-converting enzyme (ACE) concentration but not renal ACE [180]. These results indicate activation of the fetal RAS in IUGR and suggest that responsiveness of the fetoplacental vasculature to the peptide is not diminished as would be expected from the elevated plasma angiotensin II (ANG II) levels [178]. Fetal RAS is related to the production and response to prostaglandins, which has been found to be increased in fetal sheep during IUGR [181].

Genetic or pharmacological alterations in the RAS are also known to alter kidney development. When ACE inhibitors are used during pregnancy, especially during the second and third trimester, they have been shown to be fetotoxic, resulting in fetal hypotension, renal tubular dysplasia and anuria-oligohydramnion [182, 183]. These effects of ACE inhibition in the developing kidney are due to a reduction in the renal expression of critical growth factors [184], possibly mediated by angiotensin II receptor type 1 (AT1) [185].

Nephrogenesis in the rat ends around the 8th postnatal day [12, 27, 186-191]. Treatment of neonatal rats (i.e. during active nephrogenesis) with an AT1 antagonist [192-194] or an ACE inhibitor $[192,195,196]$ leads to a decreased nephron number and an altered renal water handling, suggesting an important role for ANG II in nephrogenesis. However, not all studies show similar effects. Using proper stereological techniques, McCausland et al. [16] described no difference in glomerular number, size and morphology when neonatal rats were treated with ACE inhibitors or AT1 antagonists, even though gross vascular and tubular damage was evident.

After nephrogenesis, the RAS is likely to be upregulated after IUGR, thereby causing hyperfiltration and hypertension. At a higher age, control rats show an age-dependent decline in PRA whereas IUGR rats develop hyperreninemia [173]. After maternal food restriction, 4-month-old rats show increased ANG II and plasma aldosterone levels [118].

At the age of 19 years, PRA was not related to birth weight $z$-score in humans [197]. When hypertension has developed, PRA and ANG II levels are found to be the same in rats after prenatal protein restriction $[124,134]$, but a greater and prolonged response to ANG II has been shown [140] as well as an enhanced expression of AT1 receptor, indicating a faltering downregulation [198]. Nine-month-old sheep born after maternal food restriction show similar AT1 and AT2 receptor expression, but an increase in renal cortex ACE expression [116]. ACE activity in humans shows no correlation with birth weight at birth and 1 month of age, but there is a negative cor- 
relation at the age of 3 months [199]. In rats, plasma [124] and pulmonary ACE activity is raised $[118,122]$, but renal ACE activity is unaltered [118, 129]. In 3-month-old pigs, renal and pulmonary ACE concentration is reduced with no difference in plasma ACE concentration [200]. The higher ACE activity is likely to contribute to the hypertension that is linked to IUGR. Control of the glomerular hypertension with ACE inhibitors has been shown to be effective in preventing glomerular damage and hypertension: this has been described after IUGR [127, 201], surgical renal mass reduction [202] and in hypertensive rat strains [203-207]. However, human studies are lacking, which makes it preliminary to suggest such a treatment in men.

Even though studies show conflicting results, most papers suggest that growth failure induces suppression of the fetal RAS, which could be a causal pathway to explain the reduced nephron number. However, in later life the RAS is activated inappropriately, which may contribute to hypertension. Another possible causeway can be the renal sympathetic nerve activity, which has been shown to be increased after induced uteroplacental insufficiency in the rat [160]. This can lead to a reset hyperfiltration, after which RAS is normalized or even reduced while the hyperfiltration and hypertension persist.

\section{Insulin-Like Growth Factor I}

In rodent kidney development, insulin-like growth factor I (IGF-I) plays an important role in metanephric morphogenesis [208, 209]: blocking IGF-I expression with antibodies [210] or the IGF-I receptor with antisense oligonucleotides [211] leads to an impaired development. Reduced amounts of circulating IGF lead to a nephron deficit [212] and early glomerulosclerosis [213], whereas treating IGF-deficient mice with IGF-I increases the number of glomeruli [209].

Variations in the IGF-I gene are associated with LBW in some populations [214] but not in all [215], and IGF-I levels are known to be reduced in cord blood from IUGR fetuses [216-218], newborn runt pigs [219] and fetal IUGR rats [220].

In kidney development, there is an interaction between the RAS and IGF-I. ACE inhibition in neonatal rats leads to an increased renal expression of IGFBP-1 [221], thereby inhibiting IGF-I action. By adding IGF-I to the ACE inhibition, the animals show normalized renal function and histology [23]. After long-term IGF-I infusion in fetal sheep, the RAS is intensely activated and kidney mass has increased [222]. IGF-I may therefore be a possible link in the association between IUGR and renal developmental problems.

\section{Nitric Oxide}

An important system for the kidney also involves the endothelial function of arteries and the nitric oxide (NO) system. In utero, NO production is upregulated to maintain a low resistance in the fetoplacental circulation [223]. IUGR newborns exhibit a higher endogenous NO production in the first $48 \mathrm{~h}$ of life [224].

IUGR rats showed a higher NO excretion at the age of 4 weeks, but a similar excretion at the age of 8 weeks [225]. In adult IUGR rats, endothelial dysfunction in association with a decrease in activity and expression of endothelial NO synthase was described [226, 227]. Others have shown a diminished $\mathrm{NO}$-dependent vasorelaxation [111, 138, 228-231]. Deficiency of NO, induced by exogenous inhibition of $\mathrm{NO}$ generation by arginine analogues leads to hypertension [232-234], and increased levels of PRA [234, 235], suggesting a role of RAS activation through endogenous NO inhibition after IUGR.

\section{Uric Acid}

The role of uric acid, which decreases the production of $\mathrm{NO}$ and produces endothelial dysfunction [236], is subject of renewed interest [237]. An inverted relationship between birth weight and serum uric acid has been shown [238]. Several reports associate a higher serum uric acid level with increased blood pressure [239, 240], cardiovascular events [241,242] and progression of renal disease [243]. A recent report shows that uric acid leads to glomerular hypertension by inducing arteriolopathy of preglomerular vessels [244]. The serum uric acid level is influenced by renal tubular function, since the uric acid reabsorption is linked to proximal sodium reabsorption. Since IUGR leads to an increased tubular sodium reabsorption [97], uric acid may possibly be a causative agent linking IUGR and adult diseases.

\section{Apoptosis}

Nephrogenesis is a process that requires structural formation and reformation, in which apoptosis plays an important role [25, 28-34]. As IUGR influences the for- 
mation of nephrons, it has been suggested that apoptosis clears more progenitor cells during development. In fact, apoptosis is found to be altered by IUGR: rats exhibit an increased renal apoptosis as shown by TUNEL assay [34, $133,155]$. Juvenile IUGR rats show an increased caspase3 activity, which is necessary for DNA fragmentation that characterizes apoptosis [155]. Levels of Bcl-2 (an antiapoptosis protein) mRNA are reduced, while levels of an apoptosis-related protein (Bax) are increased [155]. This is related to an altered p53 gene expression, which is a known regulator of apoptosis-related proteins [155]. Later in life, no effect of IUGR was described: in kidneys from 9-month-old sheep, similar levels of apoptosis and caspase- 3 activity were found after maternal food restriction [116].

\section{Short-Term Consequences}

In utero, the developing kidney is already functionally affected by growth restriction: fetal urine production, measured by ultrasound, and glomerular filtration rate (GFR) are decreased [68, 245].

Directly postnatal, LBW infants show a higher fractional sodium excretion and decreased glomerular filtration $[246,247]$. We have shown that in 1-day-old neonates, the birth weight $\mathrm{z}$-score is associated with the clearance of amikacin, which is a marker for GFR [Schreuder et al., unpubl. data]. Clearance of vancomycin is also lower in LBW neonates [248]. Renal artery blood flow has been shown to be lower in LBW infants [249]. A recent study in extremely LBW infants, born both premature with normal birth weight as well as premature with IUGR, demonstrated that GFR and tubular functions are impaired at the age of 6-12 years when compared with term controls [250]. No difference between the groups born with low versus appropriate birth weight for gestational age was noted. The authors conclude that being born prematurely will impair nephrogenesis, with no additional unfavorable effect of the IUGR [250]. Prematurity has been identified before as a risk factor, and results in a lower glomerular number [64], a high percentage of renal failure in the neonatal period, and an increased risk of renal insufficiency later in life [251]. A recent study in preterm children showed a negative association between GFR and birth weight and between albumin-creatinine ratio and birth weight at the age of 19 years [252]. In contrast, other studies in adolescents described no influence of birth weight on GFR and proteinuria [253, 254].

\section{'First Hit-Second Hit' Hypothesis}

According to the 'first hit-second hit' hypothesis [130], the low nephron number influences the presentation and course of accompanying renal disease, thus altering the prognosis. This was first described by Duncan et al. [255] in patients with idiopathic membranous nephropathy, who showed a correlation between birth weight and slopes of reciprocal creatinine regression lines. In children with IgA nephropathy, LBW is associated with a higher incidence of arterial hypertension, and a higher percentage of sclerotic glomeruli in renal biopsy [256]. Minimal change nephrotic syndrome in children with IUGR has an unfavorable course, leading to more relapses, a higher incidence of steroid dependency and more need for cytotoxic agents and cyclosporine [257-259]. Associations between birth weight and diabetic nephropathy [260-262] or renal damage due to urinary tract infection [263] have been reported, but are not undisputed [264-266]. However, a study in rats after prenatal glucocorticoids shows an increased susceptibility to cell death in renal cells [267], which may be the pathway to explain the difference in renal damage after urinary tract infection.

IUGR influences renal function in infancy and childhood, but also aggravates additional renal diseases, possibly as a result of the nephron endowment and subsequent hyperfiltration.

\section{Long-Term Consequences}

The lower number of nephrons is affected in the long run by both hypertrophy and hyperfiltration, leading to glomerular damage and hypertension.

Studying a group of LBW women aged 23-26 years, Kistner et al. [254] describe no significant difference in proteinuria or mean GFR, even though there are more individuals with an impaired GFR in this group. This is in line with the results of Yudkin et al. [268] who reported no association between albuminuria in adulthood (range 47-75 years of age) and any measure of size at birth, even though there is a higher incidence of microalbuminuria in the group with the thinnest individuals at birth. An increase in albuminuria has also been described in adults after prenatal exposure to the Dutch famine in mid gestation [269]. In a recent study in 19year-old subjects born very preterm, Keijzer-Veen et al. [252] describe an increase in microalbuminuria and serum creatinine, and a lower GFR after IUGR. 
In a group of adult Aborigines, an inverse relationship between birth weight and albumin/creatinine ratio is found $[87,270]$. At higher ages, data supports the association between LBW and increased susceptibility to early-onset ESRD [87-90].

Part of the compensation for the nephron endowment consists of glomerular hypertrophy. An increase in the size of glomeruli is also seen in an early phase of kidney damage [91, 92], and glomerular enlargement in donor kidneys is a risk factor for late allograft dysfunction [271, 272]. A combination of a higher incidence of glomerular enlargement and diabetic nephropathy and glomerulosclerosis has been shown in various indigenous populations, like Pima Indians $[273,274]$ and Australian Aborigines $[76,275,276]$. In a large Aboriginal population a decrease in birth weight correlates with an increase in albuminuria from childhood and overt albuminuria by early adult life [277]. Larger kidneys also seem to be a marker for subsequent nephropathy in patients with diabetes mellitus [278].

Renal cell cancer is associated with hypertension and diabetes mellitus that are both long-term consequences of LBW $[279,280]$. In one study though, an association between birth weight and renal cell cancer has been found only in men with a birth weight of over 3,500 g: LBW did not show a clear association [281].

In conclusion, IUGR leads to fewer and larger glomeruli, which is associated with proteinuria and hypertension in the long run.

\section{Renal Mass Reduction in Men}

A comparison is made with situations where the nephron number is reduced by other causes, e.g. nephrectomy due to nonrenal disease or for donor purposes. However, these results have to be interpreted with caution since the reduction in kidney mass may not have taken place during development but in adulthood. There is a known difference in compensation after renal ablation depending on sex [282-285] and age: compensation is more pronounced when renal reduction is performed before completion of nephrogenesis and development [188, 286294]. This means that the maladaptive resetting that can be seen after IUGR is different from the changes seen when nephrectomy is performed in adults [295].

After nephrectomy in childhood the remaining kidney enlarges and GFR rises to around 75\% of normal values for 2 kidneys [287, 296-299]. Renal reserve capacity decreases during the years after nephrectomy [300]. In the long run, this adaptation is lost, leading to a decrease in GFR, augmented albuminuria and more glomerulosclerosis in most [299, 301-303] but not all reports [297, 298]. Even after uninephrectomy in adults, when GFR rises to $60-70 \%$ of normal values for 2 kidneys [304, 305], hypertension and proteinuria are described [306-317] although most studies report no or small risks for hypertension and renal damage or failure [292, 318-325].

Renal agenesis may be a more reliable comparison in terms of the timing of renal mass reduction. It leads to compensatory renal growth $[296,326]$ and an increased risk of hypertension and kidney failure in adulthood with low GFR, elevated urinary protein excretion and sclerosing glomerular lesions [301, 310, 314, 327-332], even though not all studies show this [322]. In a cohort of 66 patients with congenital solitary kidneys, we have shown that $50 \%$ of these children are hypertensive, using antihypertensive drugs, or have microalbuminuria at a mean age of 9 years [Schreuder et al., unpubl. data]. These data warrant regular checkups of patients with congenital renal mass reduction or nephrectomy in childhood.

\section{Experimental Renal Mass Reduction}

Several animal models are used to study the effect of a nephron endowment on long-term kidney function. Various rat strains show a lower number of nephrons, like the MWF [333], spontaneous hypertensive [334], Milan hypertensive [335] and Prague hypertensive rat $[336,337]$. When compared with their respective controls, this results in hyperfiltration, glomerular capillary hypertension, progressive proteinuria and accelerated glomerular sclerosis [81,338]. When a kidney from a hypertensive rat strain is transplanted into a normotensive rat, hypertension develops and vice versa [339-350], which leads to the conclusion that blood pressure travels with the kidney $[351,352]$. However, a recent study showed a lower blood pressure but the same number of glomeruli in the F2 population after crossbreeding a hypertensive with a normotensive rat strain, leading to the conclusion that there is no direct relationship between the nephron number and blood pressure [353].

To induce a low glomerular number, several genetic models are available as well. In mice, a reduced number of glomeruli can be induced by the knockout of one allele for an essential factor for kidney development, i.e. glial cell line-derived neurotrophic factor (GDNF) [354, 355], by overexpression of insulin growth factor binding protein (IGFBP) [212], or by a specific mutation [356]. 
Another approach uses a surgical reduction of the nephron number in the fetal or neonatal developmental stage in order to mimic the effect of IUGR on the kidney. In sheep, fetal uninephrectomy leads to diminished renal function later in life $[357,358]$. Neonatal uninephrectomy in rats leads to larger glomeruli, hyperfiltration, augmented proteinuria and (salt-sensitive) hypertension $[295,359,360]$.

\section{Concluding Remarks}

Nephrogenesis is a complex process that requires a fine balance of many factors. IUGR leads to LBW, but can also disturb this balance leading to a low nephron endowment.
Activation of the RAS, inhibition of NO and IGF-I, raised tubular sodium reabsorption and increased serum uric acid levels are mechanisms that are associated with IUGR and a low glomerular number and may explain the longterm consequences on blood pressure and renal function. The compensatory glomerular hyperfiltration may aggravate kidney diseases and is likely to result in systemic hypertension and renal damage and failure. Further study is required to unravel the mechanisms that result in IUGR and the pathways that explain the association between IUGR and adult diseases. This should eventually lead to interventions to optimize fetal growth, and to prevent adult diseases when IUGR is present. Until then, IUGR and renal mass reduction in childhood are important factors that researchers and clinicians need to acknowledge.

\section{References}

-1 Barker DJ, Osmond C: Infant mortality, childhood nutrition, and ischaemic heart disease in England and Wales. Lancet 1986;i:1077-1081.

-2 Hales CN, Barker DJ, Clark PM, Cox LJ, Fall C, Osmond C, Winter PD: Fetal and infant growth and impaired glucose tolerance at age 64. BMJ 1991;303:1019-1022.

$\checkmark 3$ Law CM, de Swiet M, Osmond C, Fayers PM, Barker DJ, Cruddas AM, Fall CH: Initiation of hypertension in utero and its amplification throughout life. BMJ 1993;306:24-27.

$\checkmark 4$ Barker DJ: Fetal origins of coronary heart disease. BMJ 1995;311:171-174.

$\checkmark 5$ Lopes AA, Port FK: The low birth weight hypothesis as a plausible explanation for the black/white differences in hypertension, non-insulin-dependent diabetes, and endstage renal disease. Am J Kidney Dis 1995; 25:350-356.

6 Huxley RR, Shiell AW, Law CM: The role of size at birth and postnatal catch-up growth in determining systolic blood pressure: a systematic review of the literature. J Hypertens 2000;18:815-831.

7 Godfrey KM, Barker DJ: Fetal nutrition and adult disease. Am J Clin Nutr 2000;71: 1344S-1352S

$\checkmark 8$ Barker DJ: The malnourished baby and infant. Br Med Bull 2001;60:69-88.

$\checkmark 9$ Hales CN, Barker DJ: The thrifty phenotype hypothesis. Br Med Bull 2001;60:5-20.

$\checkmark 10$ Hales CN, Ozanne SE: For debate: fetal and early postnatal growth restriction lead to diabetes, the metabolic syndrome and renal failure. Diabetologia 2003;46:1013-1019.

11 Aperia A, Celsi G: Ontogenic processes in nephron epithelia. Structure, enzymes, and function; in Seldin DW, Giebisch G (eds): The Kidney: Physiology and Pathophysiology. New York, Raven Press, 1992, vol2, pp $803-828$.
12 Nigam SK, Aperia AC, Brenner BM: Development and maturation of the kidney; in Brenner BM (ed): Brenner and Rector's the Kidney. London, Saunders, 1996, vol 5, pp 72-98.

13 Hall JE, Brands MW: The renin-angiotensin-aldosterone systems. Renal mechanisms and circulatory homeostasis; in Seldin DW Giebisch G (eds): The Kidney: Physiology and Pathophysiology. New York, Raven Press, 1992, vol 2, pp 1455-1504.

14 Yosipiv IV, el Dahr SS: Activation of angiotensin-generating systems in the developing rat kidney. Hypertension 1996;27:281-286.

15 Schutz S, Le Moullec JM, Corvol P, Gasc JM: Early expression of all the components of the renin-angiotensin-system in human development. Am J Pathol 1996;149:2067-2079.

-16 McCausland JE, Bertram JF, Ryan GB, Alcorn D: Glomerular number and size following chronic angiotensin II blockade in the postnatal rat. Exp Nephrol 1997;5:201-209.

17 Wintour EM: The renin-angiotensin system and the development of the kidney. Trends Endocrinol Metab 1997;8:199-207.

18 Guron G, Friberg P: An intact renin-angiotensin system is a prerequisite for normal renal development. J Hypertens 2000;18:123137.

19 Iosipiv IV, Schroeder M: A role for angiotensin II AT1 receptors in ureteric bud cell branching. Am J Physiol Renal Physiol 2003; 285:F199-F207.

20 Liu ZZ, Wada J, Alvares K, Kumar A, Wallner EI, Kanwar YS: Distribution and relevance of insulin-like growth factor-I receptor in metanephric development. Kidney Int 1993;44:1242-1250.
21 Matsell DG, Delhanty PJ, Stepaniuk O, Goodyear C, Han VK: Expression of insulinlike growth factor and binding protein genes during nephrogenesis. Kidney Int 1994;46: 1031-1042.

22 Hammerman MR: Growth factors in renal development. Semin Nephrol 1995;15:291299.

23 Nilsson AB, Nitescu N, Chen Y, Guron GS, Marcussen N, Matejka GL, Friberg P: IGF-I treatment attenuates renal abnormalities induced by neonatal ACE inhibition. Am J Physiol Regul Integr Comp Physiol 2000; 279:R1050-R1060.

24 Flyvbjerg A, Schrijvers BF, De Vriese AS, Tilton RG, Rasch R: Compensatory glomerular growth after unilateral nephrectomy is VEGF dependent. Am J Physiol Endocrinol Metab 2002;283:E362-E366.

25 Okada T, Iwamoto A, Mukamoto M, Nakamura J, Kusakabe K, Kiso Y, Morioka H, Morikawa Y: Perinatal development of the rat kidney: apoptosis and epidermal growth factor. Congenit Anom (Kyoto) 2003;43:161167.

26 Kanwar YS, Wada J, Lin S, Danesh FR, Chugh SS, Yang Q, Banerjee T, Lomasney JW: Update of extracellular matrix, its receptors, and cell adhesion molecules in mammalian nephrogenesis. Am J Physiol Renal Physiol 2004;286:F202-F215.

27 Jung JY, Song JH, Li C, Yang CW, Kang TC, Won MH, Jeong YG, Han KH, Choi KB, Lee $\mathrm{SH}, \mathrm{Kim}$ J: Expression of epidermal growth factor in the developing rat kidney. Am J Physiol Renal Physiol 2005;288:F227-F235.

28 Koseki C, Herzlinger D, al Awqati Q: Apoptosis in metanephric development. J Cell Biol 1992;119:1327-1333. 
$\checkmark 29$ Coles HS, Burne JF, Raff MC: Large-scale normal cell death in the developing rat kidney and its reduction by epidermal growth factor. Development 1993;118:777-784.

>30 Winyard PJ, Nauta J, Lirenman DS, Hardman P, Sams VR, Risdon RA, Woolf AS: Deregulation of cell survival in cystic and dysplastic renal development. Kidney Int 1996; 49:135-146.

-31 Sorenson CM: Life, death and kidneys: regulation of renal programmed cell death. Curr Opin Nephrol Hypertens 1998;7:5-12.

$\checkmark 32$ Woolf AS, Welham SJ: Cell turnover in normal and abnormal kidney development. Nephrol Dial Transplant 2002;17(suppl 9): 2-4.

33 Pole RJ, Qi BQ, Beasley SW: Patterns of apoptosis during degeneration of the pronephros and mesonephros. J Urol 2002;167:269-271.

34 Welham SJ, Wade A, Woolf AS: Protein restriction in pregnancy is associated with increased apoptosis of mesenchymal cells at the start of rat metanephrogenesis. Kidney Int 2002;61:1231-1242.

-35 Vilar J, Gilbert T, Moreau E, Merlet-Benichou C: Metanephros organogenesis is highly stimulated by vitamin A derivatives in organ culture. Kidney Int 1996;49:1478-1487.

$\checkmark 36$ Amri K, Freund N, Vilar J, Merlet-Benichou C, Lelievre-Pegorier M: Adverse effects of hyperglycemia on kidney development in rats: in vivo and in vitro studies. Diabetes 1999;48:2240-2245.

\$37 Merlet-Benichou C: Influence of fetal environment on kidney development. Int J Dev Biol 1999;43:453-456.

-38 Amri K, Freund N, Van Huyen JP, MerletBenichou C, Lelievre-Pegorier M: Altered nephrogenesis due to maternal diabetes is associated with increased expression of IGFII/mannose-6-phosphate receptor in the fetal kidney. Diabetes 2001;50:1069-1075.

39 Potter EL, Thierstein ST: Glomerular development in the kidney as an index of fetal maturity. J Pediatr 1943;22:695-706.

$\checkmark 40$ MacDonald MS, Emery JL: The late intrauterine and postnatal development of human renal glomeruli. J Anat 1959;93:331-340.

$\checkmark 4$ Hinchliffe SA, Sargent PH, Howard CV, Chan YF, van Velzen D: Human intrauterine renal growth expressed in absolute number of glomeruli assessed by the disector method and Cavalieri principle. Lab Invest 1991;64: 777-784.

42 Lizardo-Daudt HM, Edelweiss MI, Santos FT, Schumacher R: Diagnosis of the human fetal age based on the development of the normal kidney. J Bras Patol Med Lab 2002; 38:135-139.

43 Saeki T: Über die Zahl und die Grösse der Glomeruli in der Niere einiger Säugetiere. Acta Sch Med Univ Imp Kioto 1925;8:189196.

44 Vimtrup BJ: On the number, shape, structure, and surface area of the glomeruli in the kidneys of man and mammals. Am J Anat 1928;41:123-151.
45 Moberg E: Anzahl und Grösse der Glomeruli renales beim Menschen nebst Methoden, diese zahlenmässig festzustellen. Z Mikrosk Anat Forsch 1929;18:271-310.

46 Moore RA: The total number of glomeruli in the normal human kidney. Anat Rec 1931;48: 153-168.

47 Hayman JM, Johnston SM: Experiments on the relation of creatinine and urea clearance tests of kidney function and the number of glomeruli in the human kidney obtained at autopsy. J Clin Invest 1933;12:877-884.

48 Moritz AR, Hayman JM: The disappearance of glomeruli in chronic kidney disease. Am J Pathol 1934;80:505-518.

49 Dunnill MS, Halley W: Some observations on the quantitative anatomy of the kidney. J Pathol 1973;110:113-121.

50 McLachlan MS, Guthrie JC, Anderson CK, Fulker MJ: Vascular and glomerular changes in the ageing kidney. J Pathol 1977;121:6578 .

51 Hinchliffe SA, Howard CV, Lynch MR, Sargent PH, Judd BA, van Velzen D: Renal developmental arrest in sudden infant death syndrome. Pediatr Pathol 1993;13:333-343.

52 Nyengaard JR, Bendtsen TF: Glomerular number and size in relation to age, kidney weight, and body surface in normal man. Anat Rec 1992;232:194-201.

53 Merlet-Benichou C, Vilar J, Lelievre-Pegorier M, Moreau E, Gilbert T: Fetal nephron mass: its control and deficit. Adv Nephrol Necker Hosp 1997;26:19-45.

54 Hoy WE, Douglas-Denton RN, Hughson MD, Cass A, Johnson K, Bertram JF: A stereological study of glomerular number and volume: preliminary findings in a multiracial study of kidneys at autopsy. Kidney Int Suppl 2003;83:S31-S37.

55 Bajoria R, Sooranna SR, Ward S, D’Souza S, Hancock M: Placental transport rather than maternal concentration of amino acids regulates fetal growth in monochorionic twins: implications for fetal origin hypothesis. Am J Obstet Gynecol 2001;185:1239-1246.

56 Henriksen T, Clausen T: The fetal origins hypothesis: placental insufficiency and inheritance versus maternal malnutrition in wellnourished populations. Acta Obstet Gynecol Scand 2002;81:112-114.

57 Seckl JR, Cleasby M, Nyirenda MJ: Glucocorticoids, 11beta-hydroxysteroid dehydrogenase, and fetal programming. Kidney Int 2000;57:1412-1417.

58 Hinchliffe SA, Lynch MR, Sargent PH, Howard CV, van Velzen D: The effect of intrauterine growth retardation on the development of renal nephrons. Br J Obstet Gynaecol 1992;99:296-301.

59 Merlet-Benichou C, Gilbert T, Vilar J, Moreau E, Freund N, Lelievre-Pegorier M: Nephron number: variability is the rule. Causes and consequences. Lab Invest 1999; 79:515-527.
60 Beech DJ, Sibbons PD, Howard CV, van Velzen D: Renal developmental delay expressed by reduced glomerular number and its association with growth retardation in victims of sudden infant death syndrome and in 'normal' infants. Pediatr Dev Pathol 2000;3: 450-454.

61 Manalich R, Reyes L, Herrera M, Melendi C, Fundora I: Relationship between weight at birth and the number and size of renal glomeruli in humans: a histomorphometric study. Kidney Int 2000;58:770-773.

62 Zidar N, Cor A, Premru ST, Stajer D: Is there an association between glomerular density and birth weight in healthy humans. Nephron 1998;80:97-98

63 Hughson M, Farris AB, Douglas-Denton R, Hoy WE, Bertram JF: Glomerular number and size in autopsy kidneys: the relationship to birth weight. Kidney Int 2003;63:21132122.

64 Rodriguez MM, Gomez AH, Abitbol CL, Chandar JJ, Duara S, Zilleruelo GE: Histomorphometric analysis of postnatal glomerulogenesis in extremely preterm infants. Pediatr Dev Pathol 2004;7:17-25.

65 Rodriguez MM, Gomez A, Abitbol C, Chandar J, Montane B, Zilleruelo G: Comparative renal histomorphometry: a case study of oligonephropathy of prematurity. Pediatr Nephrol 2005;20:945-949.

66 Gubhaju L, Black MJ: The baboon as a good model for studies of human kidney development. Pediatr Res 2005;58:505-509.

67 Sato A, Yamaguchi Y, Liou SM, Sato M, Suzuki M: Growth of the fetal kidney assessed by real-time ultrasound. Gynecol Obstet Invest $1985 ; 20: 1-5$.

68 Deutinger J, Bartl W, Pfersmann C, Neumark J, Bernaschek G: Fetal kidney volume and urine production in cases of fetal growth retardation. J Perinat Med 1987;15: 307-315.

69 Konje JC, Bell SC, Morton JJ, de Chazal R, Taylor DJ: Human fetal kidney morphometry during gestation and the relationship between weight, kidney morphometry and plasma active renin concentration at birth. Clin Sci (Colch) 1996;91:169-175.

$>70$ Konje JC, Okaro CI, Bell SC, de Chazal R, Taylor DJ: A cross-sectional study of changes in fetal renal size with gestation in appropriate- and small-for-gestational-age fetuses. Ultrasound Obstet Gynecol 1997;10: 22-26.

71 Lampl M, Kuzawa CW, Jeanty P: Infants thinner at birth exhibit smaller kidneys for their size in late gestation in a sample of fetuses with appropriate growth. Am J Hum Biol 2002;14:398-406.

72 Silver LE, Decamps PJ, Korst LM, Platt LD, Castro LC: Intrauterine growth restriction is accompanied by decreased renal volume in the human fetus. Am J Obstet Gynecol 2003; 188:1320-1325.
Schreuder/Delemarre-van de Waal/ van Wijk 
73 Latini G, De Mitri B, Del Vecchio A, Chitano G, De Felice C, Zetterstrom R: Foetal growth of kidneys, liver and spleen in intrauterine growth restriction: 'programming' causing 'metabolic syndrome' in adult age. Acta Paediatr 2004;93:1635-1639.

74 Hotoura E, Argyropoulou M, Papadopoulou F, Giapros V, Drougia A, Nikolopoulos P, Andronikou S: Kidney development in the first year of life in small-for-gestational-age preterm infants. Pediatr Radiol 2005;35: 991-994.

-75 Schmidt IM, Chellakooty M, Boisen KA, Damgaard IN, Mau KC, Olgaard K, Main KM: Impaired kidney growth in low-birthweight children: distinct effects of maturity and weight for gestational age. Kidney Int 2005;68:731-740.

76 Spencer J, Wang Z, Hoy W: Low birth weight and reduced renal volume in Aboriginal children. Am J Kidney Dis 2001;37:915-920.

$\checkmark 77$ Naeye RL: Malnutrition: probable cause of fetal growth retardation. Arch Pathol 1965; 79:284-291.

78 Kaufman JM, Siegel NJ, Hayslett JP: Functional and hemodynamic adaptation to progressive renal ablation. Circ Res 1975;36: 286-293.

79 Neuringer JR, Brenner BM: Glomerular hypertension: cause and consequence of renal injury. J Hypertens Suppl 1992;10:S91-S97.

-80 Hostetter TH, Olson JL, Rennke HG, Venkatachalam MA, Brenner BM: Hyperfiltration in remnant nephrons: a potentially adverse response to renal ablation. Am J Physiol 1981;241:F85-F93.

81 Brenner BM, Anderson S: The interrelationships among filtration surface area, blood pressure, and chronic renal disease. J Cardiovasc Pharmacol 1992;19(suppl 6):S1-S7.

82 Brenner BM, Lawler EV, Mackenzie HS: The hyperfiltration theory: a paradigm shift in nephrology. Kidney Int 1996;49:1774-1777.

-83 Hostetter TH: Hyperfiltration and glomerulosclerosis. Semin Nephrol 2003;23:194-199.

84 Fogo A, Ichikawa I: Evidence for a pathogenic linkage between glomerular hypertrophy and sclerosis. Am J Kidney Dis 1991;17:666669.

85 Garrett PJ, Bass PS, Sandeman DD: Barker, Brenner, and babies - early environment and renal disease in adulthood. J Pathol 1994; 173:299-300.

86 Hales CN: Suicide of the nephron. Lancet 2001;357:136-137.

87 Hoy WE, Rees M, Kile E, Mathews JD, Wang $\mathrm{Z}$ : A new dimension to the Barker hypothesis: low birthweight and susceptibility to renal disease. Kidney Int 1999;56:1072-1077.

88 Lackland DT, Bendall HE, Osmond C, Egan BM, Barker DJ: Low birth weights contribute to high rates of early-onset chronic renal failure in the Southeastern United States. Arch Intern Med 2000;160:1472-1476.

-89 Fan Z, Lipsitz S, Egan B, Lackland D: The impact of birth weight on the racial disparity of end-stage renal disease. Ann Epidemiol 2000;10:459.
-90 Lackland DT, Egan BM, Fan ZJ, Syddall HE: Low birth weight contributes to the excess prevalence of end-stage renal disease in African Americans. J Clin Hypertens (Greenwich) 2001;3:29-31.

-91 Young RJ, Hoy WE, Kincaid-Smith P, Seymour AE, Bertram JF: Glomerular size and glomerulosclerosis in Australian aborigines. Am J Kidney Dis 2000;36:481-489.

-92 Hughson MD, Johnson K, Young RJ, Hoy WE, Bertram JF: Glomerular size and glomerulosclerosis: relationships to disease categories, glomerular solidification, and ischemic obsolescence. Am J Kidney Dis 2002;39:679-688.

93 Hayman JM, Martin JW, Miller M: Renal function and the number of glomeruli in the human kidney. Arch Intern Med 1939; 64:69-83.

94 Keller G, Zimmer G, Mall G, Ritz E, Amann $\mathrm{K}$ : Nephron number in patients with primary hypertension. N Engl J Med 2003; 348:101-108.

-95 Ortiz LA, Quan A, Weinberg A, Baum M: Effect of prenatal dexamethasone on rat renal development. Kidney Int 2001;59:16631669.

-96 Langley-Evans S, Langley-Evans A, Marchand $\mathrm{M}$ : Nutritional programming of blood pressure and renal morphology. Arch Physiol Biochem 2003;111:8-16.

-97 Manning J, Beutler K, Knepper MA, Vehaskari VM: Upregulation of renal BSC1 and TSC in prenatally programmed hypertension. Am J Physiol Renal Physiol 2002;283: F202-F206.

-98 Bains RK, Sibbons PD, Murray RD, Howard CV, van Velzen D: Stereological estimation of the absolute number of glomeruli in the kidneys of lambs. Res Vet Sci 1996;60: 122-125.

99 Bauer R, Walter B, Ihring W, Kluge H, Lampe V, Zwiener U: Altered renal function in growth-restricted newborn piglets. Pediatr Nephrol 2000;14:735-739.

100 Bauer R, Walter B, Zwiener U: Effect of severe normocapnic hypoxia on renal function in growth-restricted newborn piglets. Am J Physiol Regul Integr Comp Physiol 2000;279:R1010-R1016.

101 Jones SE, Nyengaard JR, Flyvbjerg A, Bilous RW, Marshall SM: Birth weight has no influence on glomerular number and volume. Pediatr Nephrol 2001;16:340-345.

102 Bauer R, Walter B, Bauer K, Klupsch R, Patt $\mathrm{S}$, Zwiener U: Intrauterine growth restriction reduces nephron number and renal excretory function in newborn piglets. Acta Physiol Scand 2002;176:83-90.

103 Woods LL, Weeks DA: Naturally occurring intrauterine growth retardation and adult blood pressure in rats. Pediatr Res 2004;56: 763-767.

104 Schreuder MF, Nyengaard JR, Fodor M, van Wijk JA, Delemarre-van de Waal HA: Glomerular number and function are influenced by spontaneous and induced low birth weight in rats. J Am Soc Nephrol 2005;16:2913-2919.
105 Woodall SM, Johnston BM, Breier BH, Gluckman PD: Chronic maternal undernutrition in the rat leads to delayed postnatal growth and elevated blood pressure of offspring. Pediatr Res 1996;40:438-443.

106 Lucas SR, Costa Silva VL, Miraglia SM, Zaladek GF: Functional and morphometric evaluation of offspring kidney after intrauterine undernutrition. Pediatr Nephrol 1997;11:719-723.

107 Garofano A, Czernichow P, Breant B: Postnatal somatic growth and insulin contents in moderate or severe intrauterine growth retardation in the rat. Biol Neonate 1998; 73:89-98.

108 Ozaki T, Nishina H, Hanson MA, Poston L: Dietary restriction in pregnant rats causes gender-related hypertension and vascular dysfunction in offspring. J Physiol 2001; 530:141-152.

109 Lucas SR, Miraglia SM, Zaladek GF, Machado CT: Intrauterine food restriction as a determinant of nephrosclerosis. Am J Kidney Dis 2001;37:467-476.

110 Vickers MH, Ikenasio BA, Breier BH: Adult growth hormone treatment reduces hypertension and obesity induced by an adverse prenatal environment. J Endocrinol 2002; 175:615-623.

- 11 Alves GM, Barao MA, Odo LN, Nascimento GG, Franco Md MC, Nigro D, Lucas SR, Laurindo FR, Brandizzi LI, Zaladek GF: LArginine effects on blood pressure and renal function of intrauterine restricted rats. Pediatr Nephrol 2002;17:856-862.

112 Almeida JR, Mandarim-de-Lacerda CA: Maternal gestational protein-calorie restriction decreases the number of glomeruli and causes glomerular hypertrophy in adult hypertensive rats. Am J Obstet Gynecol 2005;192:945-951.

113 Kind KL, Roberts CT, Sohlstrom AI, Katsman A, Clifton PM, Robinson JS, Owens JA: Chronic maternal feed restriction impairs growth but increases adiposity of the fetal guinea pig. Am J Physiol Regul Integr Comp Physiol 2005;288:R119-R126.

114 Gil FZ, Lucas SR, Gomes GN, Cavanal MF, Coimbra TM: Effects of intrauterine food restriction and long-term dietary supplementation with L-arginine on age-related changes in renal function and structure of rats. Pediatr Res 2005;57:724-731.

115 Desai M, Gayle D, Babu J, Ross MG: Permanent reduction in heart and kidney organ growth in offspring of undernourished rat dams. Am J Obstet Gynecol 2005;193: 1224-1232.

116 Gilbert JS, Lang AL, Grant AR, Nijland MJ: Maternal nutrient restriction in sheep: hypertension and decreased nephron number in offspring at 9 months of age. J Physiol 2005;565:137-147.

17 Campbell ME, Williams SJ, Veerareddy S, Davidge ST: Maternal nutrient restriction reduces carotid artery constriction without increasing nitric oxide synthesis in the late gestation rat fetus. Pediatr Res 2005;58: 840-844. 
-118 Riviere G, Michaud A, Breton C, VanCamp G, Laborie C, Enache M, Lesage J, Deloof S, Corvol P, Vieau D: Angiotensin-converting enzyme 2 (ACE2) and ACE activities display tissue-specific sensitivity to undernutrition-programmed hypertension in the adult rat. Hypertension 2005;46:11691174.

119 Hall SM, Zeman FJ: Kidney function of the progeny of rats fed a low protein diet. J Nutr 1968;95:49-54.

120 Zeman FJ: Effects of maternal protein restriction on the kidney of the newborn young of rats. J Nutr 1968;94:111-116.

121 Goldstein RS, Hook JB, Bond JT: The effects of maternal protein deprivation on renal development and function in neonatal rats. J Nutr 1979;109:949-957.

122 Langley SC, Jackson A A: Increased systolic blood pressure in adult rats induced by fetal exposure to maternal low protein diets. Clin Sci (Lond) 1994;86:217-222.

123 Merlet-Benichou C, Gilbert T, Muffat-Joly M, Lelievre-Pegorier M, Leroy B: Intrauterine growth retardation leads to a permanent nephron deficit in the rat. Pediatr Nephrol 1994;8:175-180.

124 Langley-Evans SC, Jackson AA: Captopril normalises systolic blood pressure in rats with hypertension induced by fetal exposure to maternal low protein diets. Comp Biochem Physiol A Physiol 1995;110:223228.

125 Muaku SM, Beauloye V, Thissen JP, Underwood LE, Fossion C, Gerard G, Ketelslegers JM, Maiter D: Long-term effects of gestational protein malnutrition on postnatal growth, insulin-like growth factor (IGF)-I, and IGF-binding proteins in rat progeny. Pediatr Res 1996;39:649-655.

126 Langley-Evans SC, Gardner DS, Jackson AA: Association of disproportionate growth of fetal rats in late gestation with raised systolic blood pressure in later life. J Reprod Fertil 1996;106:307-312.

-127 Sherman RC, Langley-Evans SC: Early administration of angiotensin-converting enzyme inhibitor captopril prevents the development of hypertension programmed by intrauterine exposure to a maternal lowprotein diet in the rat. Clin Sci (Colch) 1998;94:373-381.

128 Langley-Evans SC, Welham SJ, Jackson AA: Fetal exposure to a maternal low protein diet impairs nephrogenesis and promotes hypertension in the rat. Life Sci 1999; 64:965-974.

129 Nwagwu MO, Cook A, Langley-Evans SC: Evidence of progressive deterioration of renal function in rats exposed to a maternal low-protein diet in utero. Br J Nutr 2000;83: 79-85.

130 Gurnani A, Nenov V, Taal MW, Troy JL, Mackenzie HS, Brenner BM: Congenital nephron deficit (first hit) predicts increased renal injury in uninephrectomized rats (second hit). American Society of Nephrology Renal Week, Toronto, 2000, No A3268.
131 Zimanyi MA, Bertram JF, Black MJ: Nephron number in offspring of rats fed a low protein diet during pregnancy. Image Anal Stereol 2000;19:219-222.

132 Kwong WY, Wild AE, Roberts P, Willis AC, Fleming TP: Maternal undernutrition during the preimplantation period of rat development causes blastocyst abnormalities and programming of postnatal hypertension. Development 2000;127:4195-4202.

133 Vehaskari VM, Aviles DH, Manning J: Prenatal programming of adult hypertension in the rat. Kidney Int 2001;59:238-245.

134 Woods LL, Ingelfinger JR, Nyengaard JR, Rasch R: Maternal protein restriction suppresses the newborn renin-angiotensin system and programs adult hypertension in rats. Pediatr Res 2001;49:460-467.

135 Jones SE, Bilous RW, Flyvbjerg A, Marshall SM: Intra-uterine environment influences glomerular number and the acute renal adaptation to experimental diabetes. Diabetologia 2001;44:721-728.

136 Courreges MC, Macagno ME, Diaz ML, Monserrat AJ: Gestational protein restriction induces a reduced number of glomeruli in the young. Nutr Res 2002;22:14971505.

137 Jackson AA, Dunn RL, Marchand MC, Langley-Evans SC: Increased systolic blood pressure in rats induced by a maternal lowprotein diet is reversed by dietary supplementation with glycine. Clin Sci (Lond) 2002;103:633-639.

138 Brawley L, Itoh S, Torrens C, Barker A, Bertram C, Poston L, Hanson M: Dietary protein restriction in pregnancy induces hypertension and vascular defects in rat male offspring. Pediatr Res 2003;54:83-90.

139 Sahajpal V, Ashton N: Renal function and angiotensin AT1 receptor expression in young rats following intrauterine exposure to a maternal low-protein diet. Clin Sci (Lond) 2003;104:607-614.

140 McMullen S, Gardner DS, Langley-Evans SC: Prenatal programming of angiotensin II type 2 receptor expression in the rat. $\mathrm{Br} \mathrm{J}$ Nutr 2004;91:133-140.

141 Woods LL, Weeks DA, Rasch R: Programming of adult blood pressure by maternal protein restriction: role of nephrogenesis. Kidney Int 2004;65:1339-1348.

142 Zimanyi MA, Bertram JF, Black MJ: Does a nephron deficit in rats predispose to saltsensitive hypertension? Kidney Blood Press Res 2004;27:239-247.

143 McMullen S, Langley-Evans SC: Sex-specific effects of prenatal low-protein and carbenoxolone exposure on renal angiotensin receptor expression in rats. Hypertension 2005;46:1374-1380.

144 Lelievre-Pegorier M, Vilar J, Ferrier ML, Moreau E, Freund N, Gilbert T, MerletBenichou C: Mild vitamin A deficiency leads to inborn nephron deficit in the rat. Kidney Int 1998;54:1455-1462.
145 Battista MC, Oligny LL, St Louis J, Brochu $\mathrm{M}$ : Intrauterine growth restriction in rats is associated with hypertension and renal dysfunction in adulthood. Am J Physiol Endocrinol Metab 2002;283:E124-E131.

146 Vidonho AF Jr, da Silva AA, Catanozi S, Rocha JC, Beutel A, Carillo BA, Furukawa LN, Campos RR, Toledo Bergamaschi CM, Carpinelli AR, Quintao EC, Dolnikoff MS, Heimann JC: Perinatal salt restriction: a new pathway to programming insulin resistance and dyslipidemia in adult Wistar rats. Pediatr Res 2004;56:842-848.

147 Lewis RM, Forhead AJ, Petry CJ, Ozanne SE, Hales CN: Long-term programming of blood pressure by maternal dietary iron restriction in the rat. Br J Nutr 2002;88:283290.

148 Lisle SJ, Lewis RM, Petry CJ, Ozanne SE, Hales CN, Forhead AJ: Effect of maternal iron restriction during pregnancy on renal morphology in the adult rat offspring. Br J Nutr 2003;90:33-39.

149 Louey S, Cock ML, Stevenson KM, Harding R: Placental insufficiency and fetal growth restriction lead to postnatal hypotension and altered postnatal growth in sheep. Pediatr Res 2000;48:808-814.

150 Mitchell EK, Louey S, Cock ML, Harding R, Black MJ: Nephron endowment and filtration surface area in the kidney after growth restriction of fetal sheep. Pediatr Res 2004; 55:769-773.

151 Lafeber HN, Rolph TP, Jones CT: Studies on the growth of the fetal guinea pig. The effects of ligation of the uterine artery on organ growth and development. J Dev Physiol 1984;6:441-459.

152 Ogata ES, Bussey ME, LaBarbera A, Finley S: Altered growth, hypoglycemia, hypoalaninemia, and ketonemia in the young rat: postnatal consequences of intrauterine growth retardation. Pediatr Res 1985;19:32-37.

153 Bassan H, Trejo LL, Kariv N, Bassan M, Berger E, Fattal A, Gozes I, Harel S: Experimental intrauterine growth retardation alters renal development. Pediatr Nephrol 2000;15:192-195.

154 Zhang DY, Lumbers ER, Simonetta G, Wu JJ, Owens JA, Robinson JS, McMillen IC: Effects of placental insufficiency on the ovine fetal renin-angiotensin system. Exp Physiol 2000;85:79-84.

155 Pham TD, MacLennan NK, Chiu CT, Laksana GS, Hsu JL, Lane RH: Uteroplacental insufficiency increases apoptosis and alters p53 gene methylation in the full-term IUGR rat kidney. Am J Physiol Regul Integr Comp Physiol 2003;285:R962-R970.

-156 Alexander BT: Placental insufficiency leads to development of hypertension in growthrestricted offspring. Hypertension 2003;41: 457-462.

157 Briscoe TA, Rehn AE, Dieni S, Duncan JR, Wlodek ME, Owens JA, Rees SM: Cardiovascular and renal disease in the adolescent guinea pig after chronic placental insufficiency. Am J Obstet Gynecol 2004;191:847855. 
-158 Sanders M, Fazzi G, Janssen G, Blanco C, De Mey J: Prenatal stress changes rat arterial adrenergic reactivity in a regionally selective manner. Eur J Pharmacol 2004;488: 147-155.

159 Sanders MW, Fazzi GE, Janssen GM, de Leeuw PW, Blanco CE, De Mey JG: Reduced uteroplacental blood flow alters renal arterial reactivity and glomerular properties in the rat offspring. Hypertension 2004;43:1283-1289.

$\checkmark 160$ Alexander BT, Hendon AE, Ferril G, Dwyer TM: Renal denervation abolishes hypertension in low-birth-weight offspring from pregnant rats with reduced uterine perfusion. Hypertension 2005;45:754-758.

-161 Schreuder MF, Fodor M, van Wijk JA, Delemarre-van de Waal HA: Association of birth weight with cardiovascular parameters in adult rats during baseline and stressed conditions. Pediatr Res 2006;59: 126-130.

162 Sanders MW, Fazzi GE, Janssen GM, Blanco CE, De Mey JG: High sodium intake increases blood pressure and alters renal function in intrauterine growth-retarded rats. Hypertension 2005;46:71-75

-163 Carter AM, Kingston MJ, Han KK, Mazzuca DM, Nygard K, Han VK: Altered expression of IGFs and IGF-binding proteins during intrauterine growth restriction in guinea pigs. J Endocrinol 2005;184:179-189.

-164 Epstein MF, Farrell PM, Sparks JW, Pepe G, Driscoll SG, Chez RA: Maternal betamethasone and fetal growth and development in the monkey. Am J Obstet Gynecol 1977;127: 261-263.

-165 Celsi G, Kistner A, Aizman R, Eklof AC, Ceccatelli S, de Santiago A, Jacobson SH: Prenatal dexamethasone causes oligonephronia, sodium retention, and higher blood pressure in the offspring. Pediatr Res 1998; 44:317-322.

166 Moritz KM, Johnson K, Douglas-Denton R, Wintour EM, Dodic M: Maternal glucocorticoid treatment programs alterations in the renin-angiotensin system of the ovine fetal kidney. Endocrinology 2002;143: 4455-4463.

-167 Ortiz LA, Quan A, Zarzar F, Weinberg A, Baum M: Prenatal dexamethasone programs hypertension and renal injury in the rat. Hypertension 2003;41:328-334.

168 Martins JP, Monteiro JC, Paixao AD: Renal function in adult rats subjected to prenatal dexamethasone. Clin Exp Pharmacol Physiol 2003;30:32-37.

-169 Kutzler MA, Ruane EK, Coksaygan T, Vincent SE, Nathanielsz PW: Effects of three courses of maternally administered dexamethasone at $0.7,0.75$, and 0.8 of gestation on prenatal and postnatal growth in sheep. Pediatrics 2004;113:313-319.

170 Roghair RD, Lamb FS, Miller FJ Jr, Scholz TD, Segar JL: Early gestation dexamethasone programs enhanced postnatal ovine coronary artery vascular reactivity. Am J Physiol Regul Integr Comp Physiol 2005; 288:R46-R53.
171 Woods LL, Weeks DA: Prenatal programming of adult blood pressure: role of maternal corticosteroids. Am J Physiol Regul Integr Comp Physiol 2005;289:R955-R962.

172 Figueroa JP, Rose JC, Massmann GA, Zhang J, Acuna G: Alterations in fetal kidney development and elevations in arterial blood pressure in young adult sheep after clinical doses of antenatal glucocorticoids. Pediatr Res 2005;58:510-515.

173 Manning J, Vehaskari VM: Low birth weight-associated adult hypertension in the rat. Pediatr Nephrol 2001;16:417-422.

174 Langley-Evans SC, Welham SJ, Sherman RC, Jackson AA: Weanling rats exposed to maternal low-protein diets during discrete periods of gestation exhibit differing severity of hypertension. Clin Sci (Colch) 1996; 91:607-615.

175 Kingdom JC, Hayes M, McQueen J, Howatson AG, Lindop GB: Intrauterine growth restriction is associated with persistent juxtamedullary expression of renin in the fetal kidney. Kidney Int 1999;55:424-429.

176 Weiner CP, Robillard JE: Atrial natriuretic factor, digoxin-like immunoreactive substance, norepinephrine, epinephrine, and plasma renin activity in human fetuses and their alteration by fetal disease. Am J Obstet Gynecol 1988;159:1353-1360.

177 Tannirandorn Y, Fisk NM, Shah V, Dillon MJ, Nicolini U, Rodeck CH: Plasma renin activity in fetal disease. J Perinat Med 1990; 18:229-231.

178 Kingdom JC, McQueen J, Connell JM, Whittle MJ: Fetal angiotensin II levels and vascular (type I) angiotensin receptors in pregnancies complicated by intrauterine growth retardation. Br J Obstet Gynaecol 1993;100:476-482.

179 Williams SJ, Olson DM, Zaragoza DB, Coulter CL, Butler TG, Ross JT, McMillen IC: Cortisol infusion decreases renin, but not PGHS-2, EP2, or EP4 mRNA expression in the kidney of the fetal sheep at days 109-116. Pediatr Res 2004;55:637-644.

180 Zimmermann H, Gardner DS, Jellyman JK, Fowden AL, Giussani DA, Forhead AJ: Effect of dexamethasone on pulmonary and renal angiotensin-converting enzyme concentration in fetal sheep during late gestation. Am J Obstet Gynecol 2003;189:14671471.

181 Williams SJ, McMillen IC, Zaragoza DB, Olson DM: Placental restriction increases the expression of prostaglandin endoperoxide G/H synthase-2 and EP2 mRNA in the fetal sheep kidney during late gestation. Pediatr Res 2002;52:879-885.

182 Pryde PG, Sedman AB, Nugent CE, Barr M Jr: Angiotensin-converting enzyme inhibitor fetopathy. J Am Soc Nephrol 1993;3: 1575-1582.

183 Sedman AB, Kershaw DB, Bunchman TE: Recognition and management of angiotensin converting enzyme inhibitor fetopathy. Pediatr Nephrol 1995;9:382-385.
184 Yoo KH, Wolstenholme JT, Chevalier RL: Angiotensin-converting enzyme inhibition decreases growth factor expression in the neonatal rat kidney. Pediatr Res 1997; 42:588-592.

185 Tufro-McReddie A, Romano LM, Harris JM, Ferder L, Gomez RA: Angiotensin II regulates nephrogenesis and renal vascular development. Am J Physiol 1995;269:F110F115.

186 Larsson L: The ultrastructure of the developing proximal tubule in the rat kidney. J Ultrastruct Res 1975;51:119-139.

187 Speller AM, Moffat DB: Tubulo-vascular relationships in the developing kidney. J Anat 1977;123:487-500.

188 Larsson L, Aperia A, Wilton P: Effect of normal development on compensatory renal growth. Kidney Int 1980;18:29-35.

189 Neiss WF, Klehn KL: The postnatal development of the rat kidney, with special reference to the chemodifferentiation of the proximal tubule. Histochemistry 1981;73: 251-268.

190 Fischer E, Schnermann J, Briggs JP, Kriz W, Ronco PM, Bachmann S: Ontogeny of NO synthase and renin in juxtaglomerular apparatus of rat kidneys. Am J Physiol 1995; 268:F1164-F1176.

191 Han KH, Lim JM, Kim WY, Kim H, Madsen KM, Kim J: Expression of endothelial nitric oxide synthase in developing rat kidney. Am J Physiol Renal Physiol 2005;288: F694-F702.

192 Friberg P, Sundelin B, Bohman SO, Bobik A, Nilsson H, Wickman A, Gustafsson H, Petersen J, Adams MA: Renin-angiotensin system in neonatal rats: induction of a renal abnormality in response to ACE inhibition or angiotensin II antagonism. Kidney Int 1994;45:485-492.

193 Spence SG, Allen HL, Cukierski MA, Manson JM, Robertson RT, Eydelloth RS: Defining the susceptible period of developmental toxicity for the AT1-selective angiotensin II receptor antagonist losartan in rats. Teratology 1995;51:367-382.

194 Woods LL, Rasch R: Perinatal ANG II programs adult blood pressure, glomerular number, and renal function in rats. Am J Physiol 1998;275:R1593-R1599.

195 Guron G, Adams MA, Sundelin B, Friberg P: Neonatal angiotensin-converting enzyme inhibition in the rat induces persistent abnormalities in renal function and histology. Hypertension 1997;29:91-97.

196 Guron G, Marcussen N, Nilsson A, Sundelin B, Friberg P: Postnatal time frame for renal vulnerability to enalapril in rats. J Am Soc Nephrol 1999;10:1550-1560.

197 Keijzer-Veen MG, Finken MJ, Nauta J, Dekker FW, Hille ET, Frolich M, Wit JM, van der Heijden AJ: Is blood pressure increased 19 years after intrauterine growth restriction and preterm birth? A prospective follow-up study in The Netherlands. Pediatrics 2005;116:725-731. 
198 Vehaskari VM, Stewart T, Lafont D, Soyez C, Seth D, Manning J: Kidney angiotensin and angiotensin receptor expression in prenatally programmed hypertension. Am J Physiol Renal Physiol 2004;287:F262-F267.

199 Forsyth JS, Reilly J, Fraser CG, Struthers $\mathrm{AD}$ : Angiotensin converting enzyme activity in infancy is related to birth weight. Arch Dis Child Fetal Neonatal Ed 2004;89: F442-F444.

200 Poore KR, Forhead AJ, Gardner DS, Giussani DA, Fowden AL: The effects of birth weight on basal cardiovascular function in pigs at 3 months of age. J Physiol 2002;539: 969-978.

201 Manning J, Vehaskari VM: Postnatal modulation of prenatally programmed hypertension by dietary $\mathrm{Na}$ and ACE inhibition. Am J Physiol Regul Integr Comp Physiol 2005;288:R80-R84.

202 Anderson S, Meyer TW, Rennke HG, Brenner BM: Control of glomerular hypertension limits glomerular injury in rats with reduced renal mass. J Clin Invest 1985; 76:612-619.

203 Harrap SB, Van der Merwe WM, Griffin SA, Macpherson F, Lever AF: Brief angiotensin converting enzyme inhibitor treatment in young spontaneously hypertensive rats reduces blood pressure long-term. Hypertension 1990;16:603-614.

204 Adams MA, Bobik A, Korner PI: Enalapril can prevent vascular amplifier development in spontaneously hypertensive rats. Hypertension 1990;16:252-260.

$205 \mathrm{Wu}$ JN, Berecek KH: Prevention of genetic hypertension by early treatment of spontaneously hypertensive rats with the angiotensin converting enzyme inhibitor captopril. Hypertension 1993;22:139-146.

-206 Kost CK Jr, Li P, Jackson EK: Blood pressure after captopril withdrawal from spontaneously hypertensive rats. Hypertension 1995;25:82-87.

-207 Nakaya H, Sasamura H, Hayashi M, Saruta $\mathrm{T}$ : Temporary treatment of prepubescent rats with angiotensin inhibitors suppresses the development of hypertensive nephrosclerosis. J Am Soc Nephrol 2001;12:659666.

208 Feld S, Hirschberg R: Growth hormone, the insulin-like growth factor system, and the kidney. Endocr Rev 1996;17:423-480.

209 Rogers SA, Powell-Braxton L, Hammerman MR: Insulin-like growth factor I regulates renal development in rodents. Dev Genet 1999;24:293-298.

-210 Rogers SA, Ryan G, Hammerman MR: Insulin-like growth factors I and II are produced in the metanephros and are required for growth and development in vitro. J Cell Biol 1991;113:1447-1453.

211 Wada J, Liu ZZ, Alvares K, Kumar A, Wallner E, Makino H, Kanwar YS: Cloning of cDNA for the alpha subunit of mouse insulin-like growth factor I receptor and the role of the receptor in metanephric development. Proc Natl Acad Sci USA 1993;90: 10360-10364.
212 Doublier S, Amri K, Seurin D, Moreau E, Merlet-Benichou C, Striker GE, Gilbert T: Overexpression of human insulin-like growth factor binding protein-1 in the mouse leads to nephron deficit. Pediatr Res 2001;49:660-666.

213 Doublier S, Seurin D, Fouqueray B, Verpont MC, Callard P, Striker LJ, Striker GE, Binoux M, Baud L: Glomerulosclerosis in mice transgenic for human insulin-like growth factor-binding protein-1. Kidney Int 2000;57:2299-2307.

214 Vaessen N, Janssen JA, Heutink P, Hofman A, Lamberts SW, Oostra BA, Pols HA, van Duijn CM: Association between genetic variation in the gene for insulin-like growth factor-I and low birthweight. Lancet 2002; 359:1036-1037.

215 Johnston LB, Leger J, Savage MO, Clark AJ, Czernichow P: The insulin-like growth factor-I (IGF-I) gene in individuals born small for gestational age (SGA). Clin Endocrinol (Oxf) 1999;51:423-427.

216 Verhaeghe J, Van Bree R, Van Herck E, Laureys J, Bouillon R, Van Assche FA: C-peptide, insulin-like growth factors I and II, and insulin-like growth factor binding protein-1 in umbilical cord serum: correlations with birth weight. Am J Obstet Gynecol 1993;169:89-97.

217 Langford K, Blum W, Nicolaides K, Jones J, McGregor A, Miell J: The pathophysiology of the insulin-like growth factor axis in fetal growth failure: a basis for programming by undernutrition? Eur J Clin Invest 1994; 24:851-856.

218 Westwood M, Gibson JM, Sooranna SR, Ward S, Neilson JP, Bajoria R: Genes or placenta as modulator of fetal growth: evidence from the insulin-like growth factor axis in twins with discordant growth. Mol Hum Reprod 2001;7:387-395.

219 Ritacco G, Radecki SV, Schoknecht PA: Compensatory growth in runt pigs is not mediated by insulin-like growth factor I. J Anim Sci 1997;75:1237-1243.

220 Unterman TG, Simmons RA, Glick RP, Ogata ES: Circulating levels of insulin, insulin-like growth factor-I (IGF-I), IGF-II, and IGF-binding proteins in the small for gestational age fetal rat. Endocrinology 1993;132:327-336.

221 Nilsson AB, Friberg P, Bonquist L, Lasaitiene D, Marcussen N, Chen Y: Growth hormone aggravates renal abnormalities induced by neonatal enalapril treatment. Pediatr Nephrol 2003;18:878-886.

222 Marsh AC, Gibson KJ, Wu J, Owens PC, Owens JA, Lumbers ER: Chronic effect of insulin-like growth factor I on renin synthesis, secretion, and renal function in fetal sheep. Am J Physiol Regul Integr Comp Physiol 2001;281:R318-R326.

223 Sladek SM, Magness RR, Conrad KP: Nitric oxide and pregnancy. Am J Physiol 1997; 272:R441-R463.
224 Wijnberger LD, Krediet TG, Egberts J, van Bel F: Nitric oxide production during the early neonatal period in small-for-gestational-age infants. Acta Paediatr 2001;90: 569-572.

225 Stewart T, Jung FF, Manning J, Vehaskari VM: Kidney immune cell infiltration and oxidative stress contribute to prenatally programmed hypertension. Kidney Int 2005; 68:2180-2188

226 Holemans K, Gerber R, Meurrens K, De Clerck F, Poston L, Van Assche FA: Maternal food restriction in the second half of pregnancy affects vascular function but not blood pressure of rat female offspring. Br J Nutr 1999;81:73-79.

227 Franco MC, Arruda RM, Dantas AP, Kawamoto EM, Fortes ZB, Scavone C, Carvalho $\mathrm{MH}$, Tostes RC, Nigro D: Intrauterine undernutrition: expression and activity of the endothelial nitric oxide synthase in male and female adult offspring. Cardiovasc Res 2002;56:145-153.

228 Franco MC, Dantas AP, Akamine EH, Kawamoto EM, Fortes ZB, Scavone C, Tostes RC, Carvalho MH, Nigro D: Enhanced oxidative stress as a potential mechanism underlying the programming of hypertension in utero. JCardiovasc Pharmacol 2002;40:501-509.

229 Lamireau D, Nuyt AM, Hou X, Bernier S, Beauchamp M, Gobeil F Jr, Lahaie I, Varma DR, Chemtob S: Altered vascular function in fetal programming of hypertension. Stroke 2002;33:2992-2998.

230 Payne JA, Alexander BT, Khalil RA: Reduced endothelial vascular relaxation in growth-restricted offspring of pregnant rats with reduced uterine perfusion. Hypertension 2003;42:768-774.

231 Payne JA, Alexander BT, Khalil RA: Decreased endothelium-dependent NOcGMP vascular relaxation and hypertension in growth-restricted rats on a high-salt diet. Hypertension 2004;43:420-427.

232 Arnal JF, Warin L, Michel JB: Determinants of aortic cyclic guanosine monophosphate in hypertension induced by chronic inhibition of nitric oxide synthase. J Clin Invest 1992;90:647-652.

233 Baylis C, Mitruka B, Deng A: Chronic blockade of nitric oxide synthesis in the rat produces systemic hypertension and glomerular damage. J Clin Invest 1992;90: 278-281.

-234 Ribeiro MO, Antunes E, de Nucci G, Lovisolo SM, Zatz R: Chronic inhibition of nitric oxide synthesis. A new model of arterial hypertension. Hypertension 1992;20: 298-303.

235 Kataoka H, Otsuka F, Ogura T, Yamauchi T, Kishida M, Takahashi M, Mimura Y, Makino $\mathrm{H}$ : The role of nitric oxide and the renin-angiotensin system in salt-restricted Dahl rats. Am J Hypertens 2001; 14 : 276-285.
Schreuder/Delemarre-van de Waal/ van Wijk 
-236 Khosla UM, Zharikov S, Finch JL, Nakagawa T, Roncal C, Mu W, Krotova K, Block ER, Prabhakar S, Johnson RJ: Hyperuricemia induces endothelial dysfunction. Kidney Int 2005;67:1739-1742.

-237 Johnson RJ, Feig DI, Herrera-Acosta J, Kang DH: Resurrection of uric acid as a causal risk factor in essential hypertension. Hypertension 2005;45:18-20.

-238 Feig DI, Nakagawa T, Karumanchi SA, Oliver WJ, Kang DH, Finch J, Johnson RJ: Hypothesis: uric acid, nephron number, and the pathogenesis of essential hypertension. Kidney Int 2004;66:281-287.

-239 Alper AB Jr, Chen W, Yau L, Srinivasan SR, Berenson GS, Hamm LL: Childhood uric acid predicts adult blood pressure: the Bogalusa Heart Study. Hypertension 2005;45: 34-38.

-240 Sundstrom J, Sullivan L, D’Agostino RB, Levy D, Kannel WB, Vasan RS: Relations of serum uric acid to longitudinal blood pressure tracking and hypertension incidence. Hypertension 2005;45:28-33.

-241 Short RA, Johnson RJ, Tuttle KR: Uric acid, microalbuminuria and cardiovascular events in high-risk patients. Am J Nephrol 2005;25:36-44.

-242 Madsen TE, Muhlestein JB, Carlquist JF, Horne BD, Bair TL, Jackson JD, Lappe JM, Pearson RR, Anderson JL: Serum uric acid independently predicts mortality in patients with significant, angiographically defined coronary disease. Am J Nephrol 2005;25:45-49.

243 Kang DH, Nakagawa T, Feng L, Watanabe S, Han L, Mazzali M, Truong L, Harris R, Johnson RJ: A role for uric acid in the progression of renal disease. J Am Soc Nephrol 2002;13:2888-2897.

244 Sanchez-Lozada LG, Tapia E, Santamaria J, Avila-Casado C, Soto V, Nepomuceno T, Rodriguez-Iturbe B, Johnson RJ, HerreraAcosta J: Mild hyperuricemia induces vasoconstriction and maintains glomerular hypertension in normal and remnant kidney rats. Kidney Int 2005;67:237-247.

-245 Kurjak A, Kirkinen P, Latin V, Ivankovic D: Ultrasonic assessment of fetal kidney function in normal and complicated pregnancies. Am J Obstet Gynecol 1981;141:266270.

-246 Robinson D, Weiner CP, Nakamura KT, Robillard JE: Effect of intrauterine growth retardation on renal function on day one of life. Am J Perinatol 1990;7:343-346.

247 Vanpee M, Blennow M, Linne T, Herin P, Aperia A: Renal function in very low birth weight infants: normal maturity reached during early childhood. J Pediatr 1992;121: 784-788.

-248 Frattarelli DA, Ergun H, Lulic-Botica M, Lehr VT, Aranda JV: Vancomycin elimination in human infants with intrauterine growth retardation. Pediatr Infect Dis J 2005;24:979-983.
249 Kempley ST, Gamsu HR, Nicolaides KH: Renal artery blood flow velocity in very low birthweight infants with intrauterine growth retardation. Arch Dis Child 1993; 68:588-590.

250 Rodriguez-Soriano J, Aguirre M, Oliveros $\mathrm{R}$, Vallo A: Long-term renal follow-up of extremely low birth weight infants. Pediatr Nephrol 2005;20:579-584.

251 Abitbol CL, Bauer CR, Montane B, Chandar J, Duara S, Zilleruelo G: Long-term follow-up of extremely low birth weight infants with neonatal renal failure. Pediatr Nephrol 2003;18:887-893.

252 Keijzer-Veen MG, Schrevel M, Finken MJ, Dekker FW, Nauta J, Hille ET, Frolich M, van der Heijden BJ: Microalbuminuria and lower glomerular filtration rate at young adult age in subjects born very premature and after intrauterine growth retardation. J Am Soc Nephrol 2005;16:2762-2768.

253 Vasarhelyi B, Dobos M, Reusz GS, Szabo A, Tulassay T: Normal kidney function and elevated natriuresis in young men born with low birth weight. Pediatr Nephrol 2000;15: 96-100.

-254 Kistner A, Celsi G, Vanpee M, Jacobson SH: Increased blood pressure but normal renal function in adult women born preterm. Pediatr Nephrol 2000;15:215-220.

255 Duncan RC, Bass PS, Garrett PJ, Dathan JR: Weight at birth and other factors influencing progression of idiopathic membranous nephropathy. Nephrol Dial Transplant 1994;9:875

256 Zidar N, Cavic MA, Kenda RB, Koselj M, Ferluga D: Effect of intrauterine growth retardation on the clinical course and prognosis of IgA glomerulonephritis in children. Nephron 1998;79:28-32.

257 Zidar N, Avgustin CM, Kenda RB, Ferluga D: Unfavorable course of minimal change nephrotic syndrome in children with intrauterine growth retardation. Kidney Int 1998;54:1320-1323.

258 Sheu JN, Chen JH: Minimal change nephrotic syndrome in children with intrauterine growth retardation. Am J Kidney Dis 2001;37:909-914.

259 Na YW, Yang HJ, Choi JH, Yoo KH, Hong YS, Lee JW, Kim SK: Effect of intrauterine growth retardation on the progression of nephrotic syndrome. Am J Nephrol 2002; 22:463-467.

260 Rossing P, Tarnow L, Nielsen FS, Hansen BV, Brenner BM, Parving HH: Low birth weight. A risk factor for development of diabetic nephropathy? Diabetes 1995;44: 1405-1407.

261 Nelson RG, Morgenstern H, Bennett PH: Birth weight and renal disease in Pima Indians with type 2 diabetes mellitus. Am J Epidemiol 1998;148:650-656.

262 Nelson RG: Intrauterine determinants of diabetic kidney disease in disadvantaged populations. Kidney Int Suppl 2003;83: S13-S16.
263 Hellstrom M, Hessel H, Jacobsson B, Jodal U, Niklasson A, Wennerstrom M, Hellstrom A: Association between urinary tract infection, renal damage and birth size. Acta Paediatr 2001;90:628-631.

264 Winberg J: Does low birthweight facilitate postinfectious focal renal scarring? Acta Paediatr 2001;90:835-836.

265 Eshoj O, Vaag A, Borch-Johnsen K, FeldtRasmussen B, Beck-Nielsen H: Is low birth weight a risk factor for the development of diabetic nephropathy in patients with type 1 diabetes? A population-based casecontrol study. J Intern Med 2002;252: 524-528.

266 Jacobsen P, Rossing P, Tarnow L, Hovind P, Parving HH: Birth weight - a risk factor for progression in diabetic nephropathy? J Intern Med 2003;253:343-350.

267 Chen M, Bao W, Ceccatelli S, Celsi G: Prenatal exposure to high level of glucocorticoids increases the susceptibility of renal proximal tubular cells to apoptosis induced by uropathogenic Escherichia coli toxins. Am J Nephrol 2004;24:497-502.

268 Yudkin JS, Martyn CN, Phillips DI, Gale CR: Associations of micro-albuminuria with intra-uterine growth retardation. Nephron 2001;89:309-314.

269 Painter RC, Roseboom TJ, van Montfrans GA, Bossuyt PM, Krediet RT, Osmond C, Barker DJ, Bleker OP: Microalbuminuria in adults after prenatal exposure to the Dutch famine. J Am Soc Nephrol 2005; 16:189194.

270 Hoy WE, Rees M, Kile E, Mathews JD, McCredie DA, Pugsley DJ, Wang Z: Low birthweight and renal disease in Australian aborigines. Lancet 1998;352:1826-1827.

-271 Abdi R, Slakey D, Kittur D, Burdick J, Racusen L: Baseline glomerular size as a predictor of function in human renal transplantation. Transplantation 1998;66:329-333.

272 Li M, Nicholls KM, Becker GJ: Risk factors for late renal allograft dysfunction: effects of baseline glomerular size. J Nephrol 2002; 15:620-625.

273 Kunzelman CL, Knowler WC, Pettitt DJ, Bennett PH: Incidence of proteinuria in type 2 diabetes mellitus in the Pima Indians. Kidney Int 1989;35:681-687.

274 Schmidt K, Pesce C, Liu Q, Nelson RG, Bennett PH, Karnitschnig H, Striker LJ, Striker GE: Large glomerular size in Pima Indians: lack of change with diabetic nephropathy. J Am Soc Nephrol 1992;3:229-235.

275 Moore L, Lloyd MS, Pugsley DJ, Seymour AE: Renal disease in the Australian Aboriginal population: a pathological study. Nephrology 1996;2:315-321.

-276 Spencer JL, Silva DT, Snelling P, Hoy WE: An epidemic of renal failure among Australian Aboriginals. Med J Aust 1998;168:537541. 
-277 Hoy WE, Mathews JD, McCredie DA, Pugsley DJ, Hayhurst BG, Rees M, Kile E, Walker KA, Wang Z: The multidimensional nature of renal disease: rates and associations of albuminuria in an Australian Aboriginal community. Kidney Int 1998;54:12961304.

278 Baumgartl HJ, Sigl G, Banholzer P, Haslbeck M, Standl E: On the prognosis of IDDM patients with large kidneys. Nephrol Dial Transplant 1998;13:630-634.

279 McLaughlin JK, Chow WH, Mandel JS, Mellemgaard A, McCredie M, Lindblad P, Schlehofer B, Pommer W, Niwa S, Adami HO: International renal-cell cancer study. VIII. Role of diuretics, other anti-hypertensive medications and hypertension. Int $\mathrm{J}$ Cancer 1995;63:216-221.

280 Lindblad P, Chow WH, Chan J, Bergstrom A, Wolk A, Gridley G, McLaughlin JK, Nyren O, Adami HO: The role of diabetes mellitus in the aetiology of renal cell cancer. Diabetologia 1999;42:107-112.

-281 Bergstrom A, Lindblad P, Wolk A: Birth weight and risk of renal cell cancer. Kidney Int 2001;59:1110-1113.

282 Sesso R, Whelton PK, Klag MJ: Effect of age and gender on kidney function in renal transplant donors: a prospective study. Clin Nephrol 1993;40:31-37.

-283 Baylis C: Age-dependent glomerular damage in the rat. Dissociation between glomerular injury and both glomerular hypertension and hypertrophy. Male gender as a primary risk factor. J Clin Invest 1994;94: 1823-1829.

284 Mulroney SE, Woda C, Johnson M, Pesce C: Gender differences in renal growth and function after uninephrectomy in adult rats. Kidney Int 1999;56:944-953.

285 Mok KY, Sandberg K, Sweeny JM, Zheng W, Lee S, Mulroney SE: Growth hormone regulation of glomerular AT1 angiotensin receptors in adult uninephrectomized male rats. Am J Physiol Renal Physiol 2003;285: F1085-F1091.

286 Kaufman JM, Hardy R, Hayslett JP: Agedependent characteristics of compensatory renal growth. Kidney Int 1975;8:21-26.

-287 Aperia A, Broberger O, Wikstad I, Wilton $P$ : Renal growth and function in patients nephrectomized in childhood. Acta Paediatr Scand 1977;66:185-192.

288 Hayslett JP: Effect of age on compensatory renal growth. Kidney Int 1983;23:599602.

289 O'Donnell MP, Kasiske BL, Raij L, Keane WF: Age is a determinant of the glomerular morphologic and functional responses to chronic nephron loss. J Lab Clin Med 1985; 106:308-313.

-290 Celsi G, Jakobsson B, Aperia A: Influence of age on compensatory renal growth in rats. Pediatr Res 1986;20:347-350.
291 Okuda S, Motomura K, Sanai T, Tsuruda H, Oh Y, Onoyama K, Fujishima M: Influence of age on deterioration of the remnant kidney in uninephrectomized rats. Clin Sci (Lond) 1987;72:571-576.

292 Liu PL, Gallery ED, Grigg R, Mahony JF, Gyory AZ: Renal function in unilateral nephrectomy subjects. J Urol 1992;147:337339.

293 Schwartz MM, Bidani AK: Comparison of glomerular injury in juvenile versus mature rats in a remnant kidney model. J Lab Clin Med 1993;121:348-355.

294 Howie AJ: Age and effects of reduced renal mass. J Pathol 1995;176:321.

295 Woods LL: Neonatal uninephrectomy causes hypertension in adult rats. Am Physiol 1999;276:R974-R978.

296 Eklof O, Ringertz H: Kidney size and growth in unilateral renal agenesis and in the remaining kidney following nephrectomy for Wilms' tumor. Acta Radiol Diagn (Stockh) 1976;17:601-608.

297 Robitaille P, Mongeau JG, Lortie L, Sinnassamy P: Long-term follow-up of patients who underwent unilateral nephrectomy in childhood. Lancet 1985;i:1297-1299.

298 Wikstad I, Pettersson BA, Elinder G, Sokucu S, Aperia A: A comparative study of size and function of the remnant kidney in patients nephrectomized in childhood for Wilms' tumor and hydronephrosis. Acta Paediatr Scand 1986;75:408-414.

299 Baudoin P, Provoost AP, Molenaar JC: Renal function up to 50 years after unilateral nephrectomy in childhood. Am J Kidney Dis 1993;21:603-611.

300 Regazzoni BM, Genton N, Pelet J, Drukker A, Guignard JP: Long-term followup of renal functional reserve capacity after unilateral nephrectomy in childhood. J Urol 1998;160:844-848.

301 Wikstad I, Celsi G, Larsson L, Herin P, Aperia A: Kidney function in adults born with unilateral renal agenesis or nephrectomized in childhood. Pediatr Nephrol 1988; 2:177-182.

302 Makipernaa A, Koskimies O, Jaaskelainen J, Teppo AM, Siimes MA: Renal growth and function 11-28 years after treatment of Wilms' tumour. Eur J Pediatr 1991;150: 444-447.

303 Argueso LR, Ritchey ML, Boyle ET Jr, Milliner DS, Bergstralh EJ, Kramer SA: Prognosis of children with solitary kidney after unilateral nephrectomy. J Urol 1992;148: 747-751.

304 Pabico RC, McKenna BA, Freeman RB: Renal function before and after unilateral nephrectomy in renal donors. Kidney Int 1975;8:166-175.

305 Aurell M, Ewald J: The use of living donors. Glomerular filtration rate during the first year after donor nephrectomy. Scand J Urol Nephrol Suppl 1981;64:137-142.

306 Zucchelli P, Cagnoli L, Casanova S, Donini U, Pasquali S: Focal glomerulosclerosis in patients with unilateral nephrectomy. Kidney Int 1983;24:649-655.
307 Vincenti F, Amend WJ Jr, Kaysen G, Feduska N, Birnbaum J, Duca R, Salvatierra O: Long-term renal function in kidney donors. Sustained compensatory hyperfiltration with no adverse effects. Transplantation 1983;36:626-629.

308 Hakim RM, Goldszer RC, Brenner BM: Hypertension and proteinuria: long-term sequelae of uninephrectomy in humans. Kidney Int 1984;25:930-936.

309 Mathillas O, Attman PO, Aurell M, Blohme I, Brynger H, Granerus G, Westberg G: Long-term outcome of renal function and proteinuria in kidney transplant donors. Proc Eur Dial Transplant Assoc Eur Ren Assoc 1985;21:574-579.

310 Rugiu C, Oldrizzi L, Lupo A, Valvo E, Loschiavo C, Tessitore N, Gammaro L, Ortalda V, Fabris A, Panzetta G: Clinical features of patients with solitary kidneys. Nephron 1986;43:10-15.

311 Dunn JF, Nylander WA Jr, Richie RE, Johnson HK, MacDonell RC Jr, Sawyers JL: Living related kidney donors. A 14-year experience. Ann Surg 1986;203:637-643.

-312 Higashihara E, Horie S, Takeuchi T, Nutahara K, Aso Y: Long-term consequence of nephrectomy. J Urol 1990;143:239-243.

313 Novick AC, Gephardt G, Guz B, Steinmuller D, Tubbs RR: Long-term follow-up after partial removal of a solitary kidney. N Engl J Med 1991;325:1058-1062.

314 Argueso LR, Ritchey ML, Boyle ET Jr, Milliner DS, Bergstralh EJ, Kramer SA: Prognosis of patients with unilateral renal agenesis. Pediatr Nephrol 1992;6:412-416.

- 315 Lent V, Harth J: Nephropathy in remnant kidneys: pathological proteinuria after unilateral nephrectomy. J Urol 1994;152: 312-316.

316 Saran R, Marshall SM, Madsen R, Keavey P, Tapson JS: Long-term follow-up of kidney donors: a longitudinal study. Nephrol Dial Transplant 1997;12:1615-1621.

317 Fehrman-Ekholm I, Duner F, Brink B, Tyden G, Elinder CG: No evidence of accelerated loss of kidney function in living kidney donors: results from a cross-sectional follow-up. Transplantation 2001;72:444449.

318 Smith S, Laprad P, Grantham J: Long-term effect of uninephrectomy on serum creatinine concentration and arterial blood pressure. Am J Kidney Dis 1985;6:143-148.

319 Mathillas O, Attman PO, Aurell M, Blohme I, Brynger H, Granerus G, Westberg G: Proteinuria and renal function in kidney transplant donors 10-18 years after donor uninephrectomy. Ups J Med Sci 1985;90: 37-42.

320 Anderson CF, Velosa JA, Frohnert PP, Torres VE, Offord KP, Vogel JP, Donadio JV Jr, Wilson DM: The risks of unilateral nephrectomy: status of kidney donors 10 to 20 years postoperatively. Mayo Clin Proc 1985; 60:367-374.

Schreuder/Delemarre-van de Waal/ van Wijk 
- 321 Talseth T, Fauchald P, Skrede S, Djoseland O, Berg KJ, Stenstrom J, Heilo A, Brodwall EK, Flatmark A: Long-term blood pressure and renal function in kidney donors. Kidney Int 1986;29:1072-1076.

- 322 Schmitz A, Christensen CK, Christensen T, Solling K: No microalbuminuria or other adverse effects of long-standing hyperfiltration in humans with one kidney. Am J Kidney Dis 1989;13:131-136.

-323 Najarian JS, Chavers BM, McHugh LE, Matas AJ: 20 years or more of follow-up of living kidney donors. Lancet 1992;340:807810 .

-324 Narkun-Burgess DM, Nolan CR, Norman JE, Page WF, Miller PL, Meyer TW: Fortyfive year follow-up after uninephrectomy. Kidney Int 1993;43:1110-1115.

- 325 Kasiske BL, Ma JZ, Louis TA, Swan SK: Long-term effects of reduced renal mass in humans. Kidney Int 1995;48:814-819.

326 Hartshorne N, Shepard T, Barr M Jr: Compensatory renal growth in human fetuses with unilateral renal agenesis. Teratology 1991;44:7-10.

- 327 Kiprov DD, Colvin RB, McCluskey RT: Focal and segmental glomerulosclerosis and porteinuria associated with unilateral renal agenesis. Lab Invest 1982;46:275-281.

- 328 Thorner PS, Arbus GS, Celermajer DS, Baumal R: Focal segmental glomerulosclerosis and progressive renal failure associated with a unilateral kidney. Pediatrics 1984;73:806-810.

329 Bhathena DB, Julian BA, McMorrow RG, Baehler RW: Focal sclerosis of hypertrophied glomeruli in solitary functioning kidneys of humans. Am J Kidney Dis 1985; 5:226-232.

-330 Weinstein T, Zevin D, Gafter U, Ben Bassat $\mathrm{M}$, Levi J: Proteinuria and chronic renal failure associated with unilateral renal agenesis. Isr J Med Sci 1985;21:919-921.

-331 Gutierrez-Millet V, Nieto J, Praga M, Usera G, Martinez MA, Morales JM: Focal glomerulosclerosis and proteinuria in patients with solitary kidneys. Arch Intern Med 1986;146:705-709.

- 332 De Santo NG, Anastasio P, Spitali L, Santoro D, Capodicasa D, Cirillo E, Capasso G: Renal reserve is normal in adults born with unilateral renal agenesis and is not related to hyperfiltration or renal failure. Miner Electrolyte Metab 1997;23:283-286.

-333 Fassi A, Sangalli F, Maffi R, Colombi F, Mohamed EI, Brenner BM, Remuzzi G, Remuzzi A: Progressive glomerular injury in the MWF rat is predicted by inborn nephron deficit. J Am Soc Nephrol 1998;9:13991406.

-334 Skov K, Nyengaard JR, Korsgaard N, Mulvany MJ: Number and size of renal glomeruli in spontaneously hypertensive rats. J Hypertens 1994;12:1373-1376.
335 Menini S, Ricci C, Iacobini C, Bianchi G, Pugliese G, Pesce C: Glomerular number and size in Milan hypertensive and normotensive rats: their relationship to susceptibility and resistance to hypertension and renal disease. J Hypertens 2004;22:21852192.

336 Hellmann H, Davis JM, Thurau K: Glomerulus number and blood pressure in the Prague hypertensive rat. Kidney Int Suppl 1998;67:S211-S212.

337 Hellmann H, Davis JM, Thurau K: Blood pressure and indices of glomerular filtration area in hypertensive and normotensive Prague rats. Kidney Blood Press Res 2000; 23:385-392.

338 Kreutz R, Kovacevic L, Schulz A, Rothermund L, Ketteler M, Paul M: Effect of high $\mathrm{NaCl}$ diet on spontaneous hypertension in a genetic rat model with reduced nephron number. J Hypertens 2000;18:777-782.

339 Bianchi G, Fox U, Di Francesco GF, Giovanetti AM, Pagetti D: Blood pressure changes produced by kidney cross-transplantation between spontaneously hypertensive rats and normotensive rats. Clin Sci Mol Med 1974;47:435-448.

340 Dahl LK, Heine M, Thompson K: Genetic influence of the kidneys on blood pressure. Evidence from chronic renal homografts in rats with opposite predispositions to hypertension. Circ Res 1974;40:94-101.

341 Rettig R, Stauss H, Folberth C, Ganten D, Waldherr B, Unger T: Hypertension transmitted by kidneys from stroke-prone spontaneously hypertensive rats. Am J Physiol 1989;257:F197-F203.

-342 Rettig R, Folberth CG, Stauss H, Kopf D, Waldherr R, Baldauf G, Unger T: Hypertension in rats induced by renal grafts from renovascular hypertensive donors. Hypertension 1990;15:429-435.

343 Kopf D, Waldherr R, Rettig R: Source of kidney determines blood pressure in young renal transplanted rats. Am J Physiol 1993; 265:F104-F111.

344 Heller J, Schubert G, Havlickova J, Thurau $\mathrm{K}$ : The role of the kidney in the development of hypertension: a transplantation study in the Prague hypertensive rat. Pflugers Arch 1993;425:208-212.

345 Sander S, Rettig R, Ehrig B: Role of the native kidney in experimental post-transplantation hypertension. Pflugers Arch 1996;431:971-976.

346 Patschan O, Kuttler B, Heemann U, Uber A, Rettig R: Kidneys from normotensive donors lower blood pressure in young transplanted spontaneously hypertensive rats. Am J Physiol 1997;273:R175-R180.

347 Kouwenhoven EA, van Dokkum RP, Marquet RL, Heemann UW, de Bruin RW, IJzermans JN, Provoost AP: Genetic susceptibility of the donor kidney contributes to the development of renal damage after syngeneic transplantation. Am J Hypertens 1999;12:603-610.
348 Grisk O, Kloting I, Exner J, Spiess S, Schmidt R, Junghans D, Lorenz G, Rettig R: Longterm arterial pressure in spontaneously hypertensive rats is set by the kidney. J Hypertens 2002;20:131-138.

349 Smallegange C, Kline RL, Adams MA: Transplantation of enalapril-treated kidneys confers persistent lowering of arterial pressure in SHR. Hypertension 2003;42: 932-936.

350 Smallegange C, Hale TM, Bushfield TL, Adams MA: Persistent lowering of pressure by transplanting kidneys from adult spontaneously hypertensive rats treated with brief antihypertensive therapy. Hypertension 2004;44:89-94.

351 Rettig R, Bandelow N, Patschan O, Kuttler B, Frey B, Uber A: The importance of the kidney in primary hypertension: insights from cross-transplantation. J Hum Hypertens 1996;10:641-644.

352 Rettig R, Grisk O: The kidney as a determinant of genetic hypertension: evidence from renal transplantation studies. Hypertension 2005;46:463-468.

353 Black MJ, Briscoe TA, Constantinou M, Kett MM, Bertram JF: Is there an association between level of adult blood pressure and nephron number or renal filtration surface area? Kidney Int 2004;65:582-588.

354 Cullen-McEwen LA, Drago J, Bertram JF: Nephron endowment in glial cell line-derived neurotrophic factor (GDNF) heterozygous mice. Kidney Int 2001;60:31-36.

355 Cullen-McEwen LA, Kett MM, Dowling J, Anderson WP, Bertram JF: Nephron number, renal function, and arterial pressure in aged GDNF heterozygous mice. Hypertension 2003;41:335-340.

- 356 He C, Esposito C, Phillips C, Zalups RK, Henderson DA, Striker GE, Striker LJ: Dissociation of glomerular hypertrophy, cell proliferation, and glomerulosclerosis in mouse strains heterozygous for a mutation (Os) which induces a $50 \%$ reduction in nephron number. J Clin Invest 1996;97: 1242-1249.

357 Moritz KM, Wintour EM, Dodic M: Fetal uninephrectomy leads to postnatal hypertension and compromised renal function. Hypertension 2002;39:1071-1076.

-358 Moritz KM, Jefferies A, Wong J, Wintour EM, Dodic M: Reduced renal reserve and increased cardiac output in adult female sheep uninephrectomized as fetuses. Kidney Int 2005;67:822-828.

359 Celsi G, Bohman SO, Aperia A: Development of focal glomerulosclerosis after unilateral nephrectomy in infant rats. Pediatr Nephrol 1987;1:290-296.

360 Woods LL, Weeks DA, Rasch R: Hypertension after neonatal uninephrectomy in rats precedes glomerular damage. Hypertension 2001;38:337-342. 